\title{
COMMENT
}

\section{THE CASE FOR EXCLUSIVE TRIBAL POWER TO TAX MINERAL LESSEES OF INDIAN LANDS}

\section{INTRODUCTION}

That economic conditions on Indian reservations in America are abominable is a well-known fact. ${ }^{1}$ Indian tribal governments are in dire financial straits, without any adequate source of revenue. In light of the prevalence of abject poverty, unemployment, and lack of education among reservation Indians, the taxing of tribal members is not a feasible solution.

In a search for revenues, Indian attention has naturally focused on outside interests doing business on reservations -especially mining, oil, and power companies that have longterm leases of Indian lands. ${ }^{2}$ Theoretically, these leases are negotiated by the Indians themselves, subject to the discretionary approval of the Secretary of the Interior. ${ }^{3}$ In practice, however, the terms of leases are negotiated by the Department of the Interior and then submitted to the Indians for approval; the tribal councils play a limited role, essentially retaining a veto power over leases negotiated by the federal government. ${ }^{4}$ It has been asserted that the consideration passing to the Indians is generally quite low. ${ }^{5}$ Leases may even contain clauses by which Indian tribes covenant not to tax their lessees; or royalties under a lease may be stated to be in lieu of tribal taxation. ${ }^{6}$ Another important economic element in the leasing context is state taxation of reservation lessees. ${ }^{7}$ Indeed, such a state tax may place a

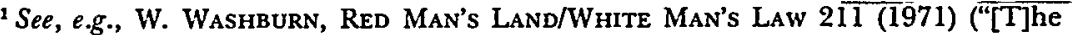
Indian is the poorest, least healthy and least educated segment of Amrican society"). See generally Comment, Indian Taxation: Underlying Policies and Present Problems, 59 CALIF. L. Rev. 1261 n.3 (1971) (collecting sources).

2 For a general discussion of how these leases are made, see L. Keliy, The Navajo Indians and Federal Indian Policy $37-76$ (1968); A. McLane, Oil and Gas Leasing on INDIAN LANDS (1955).

325 U.S.C. $\S \S 396-98$ (1970).

- R. Barsh \& J. Henderson, Management of Natural Resurces: Oil and Gas 4, 8, April 17, 1974 (unpublished paper at Harvard Law School).

5 Id. 4.

6 See text accompanying note 99 infra.

${ }^{7}$ See text accompanying notes 98-152 infra. 
far greater burden on the lessee than do the contractual royalty payments provided in the lease agreement. ${ }^{8}$

The Indian tribes are sovereign, or at least quasi-sovereign governmental bodies that perform essential governmental functions for their members. ${ }^{9}$ Naturally, the tribes would like to tax their lessees to increase the sadly depleted tribal revenues. It is the contention of this Comment that the tribes have the power to impose such a tax in the absence of the no-tax clauses in their leases. Furthermore, it is suggested that even the no-tax clauses may not be an insuperable bar, because repudiation of such clauses, indeed repudiation of the entire leases, could be sustained as a legitimate action by a sovereign tribe which cannot be held to have irrevocably contracted away an essential attribute of its sovereignty, the power to tax.

The reassertion of the right of a tribe to tax its lessees would be a nearly hollow victory, however, if the states were permitted to continue their present taxation of the Indians' lessees. This Comment will seek to show: (1) that state taxation of reservation lessees is impermissible if it interferes with Indian tribal revenue-raising ability or with a tribe's capacity to govern itself (often the two are interrelated); and (2) that federal statutes which have been interpreted to permit such taxation have been misconstrued.

Furthermore, this Comment will seek to demonstrate that an Indian tribe should have under current law an action for damages against the United States based on breach of fiduciary duty to the tribe in cases where the Government has negotiated leases yielding insufficient consideration or containing unconscionable restrictions on Indian power. This duty follows from the relationship the Government itself has forced upon the Indian tribes, which has been characterized as the relationship between a guardian and his ward.

Throughout this Comment some generalizations are made about tribal, state, and federal powers. It should be recognized at the outset that the conclusions of the present analysis may be subject to some variation, depending on the treaties and federal

${ }^{8}$ See text accompanying note 118 infra.

${ }^{9}$ See F. Cohen, Handbook of Federal Indian Law $122-49$ (1942). [hereinafter cited as COHEN]. Cohen's influential and comprehensive study has been revised as U.S. SOLICITOR FOR THE Department OF THE INTERIOR, FEDERAL INDIAN LAW (1958) [hereinafter cited as FEDERAL INDIAN LAw]. Many changes in Cohen's statements have been made in the newer work. See, e.g., note 37 infra \& accompanying text. See also J. White, Taxing Those They Found Here 18 n.63, $19-20$ n.65 (1972): "The subule changes in language made in Cohen's work during that revision cause one to wonder what a 1984 revision would look like." 
statutes applicable to particular tribes, and on the federal statutes defining the relationships of particular states to Indian tribes within their borders. ${ }^{10}$

\section{General Contours of Indian Sovereignty}

\section{A. The Nature of the Indian "Nation"}

Indian tribes have many of the attributes of sovereign nations. As will be described below, these include the power to tax and to regulate activities on the reservations, the power to operate court systems, the right to make treaties or their equivalent, and sovereign immunity. ${ }^{11}$ To analogize a tribe to any other familiar governmental entity-foreign nation-state, ${ }^{12}$ state of the Union, ${ }^{13}$ municipality ${ }^{14}$-is inherently unsound. Nor is it accurate to compare the Indian tribes to private organizations such as corporations. ${ }^{15}$ The nature of tribal sovereignty has, through the operation of treaties, statutes, and common law, become unique.

The first major opportunity for the Supreme Court to consider the nature of Indian tribal sovereignty came in the early 1830's. Georgia had been, to say the least, hostile to the Cherokee Indians within its borders. In Cherokee Nation $v$. Georgia, ${ }^{16}$ the tribe sought to enjoin Georgia officials from enforcing the state's laws inside the Cherokee reservation. Although recognizing the tribe as an entity capable of making a treaty with the United States, ${ }^{17}$ the Court concluded that the tribe could not maintain an action in a federal court because it was neither one of the United States nor a "foreign nation."18 The Court characterized the Indian tribes as "domestic dependent nations," relying both on historical analysis and on article I, section 8 , of the Constitution, which empowers Congress to regu-

${ }^{10}$ See McClanahan v. Arizona State Tax Comm'n, 411 U.S. 164 (1973).

${ }^{11}$ See Cohen, supra note 9 , at 122-49, 283-84.

${ }^{12}$ Cf. Native American Church v. Navajo Tribal Council, 272 F.2d 131, 134 (10th Cir. 1959) (Indian tribes are not states, but occupy a "status higher than that of states.").

${ }^{13} \mathrm{Cf}$. Cherokee Nation v. Georgia, 30 U.S. (5 Pet.) 1, 11-12 (1831); text accompanying notes 17-18 infra.

${ }^{14}$ Cf. W. WASHBURN, supra note 1, at 79: "The Indian Reorganization Act extended to the Indian community powers of self-government roughly equivalent to those possessed by incorporated towns in the United States."

${ }^{15}$ See note 93 infra.

${ }^{16} 30$ U.S. (5 Pet.) 1 (1831).

${ }^{17} \mathrm{Id}$. at 16.

${ }^{18}$ Id. at 18-20 U.S. ConsT. art. III, $\$ 2$ provides: "The judicial Power shall extend to ... Controversies between two or more States; . . . and between a State, or the Citizens thereof, and foreign States, Citizens, or Subjects." 
late commerce with the "Indian tribes," as distinct from "foreign nations" and the "several states."19

A year later, in the landmark case of Worcester $v$. Georgia, ${ }^{20}$ the Court reached the merits of the controversy between Georgia and the Cherokees in a full-blown treatment of Indian sovereignty. This case involved the constitutionality of a Georgia statute requiring white persons desiring to reside on the Indian reservation to obtain permission from the Governor of Georgia and to take an oath of allegiance to that state. Samuel Worcester, a white missionary from Vermont, had entered the Cherokee reservation to preach Christianity, with permission of the tribe and under the authority of the President of the United States, but without authorization by Georgia as prescribed by statute. $\mathrm{He}$ was convicted of violating the state law and was sentenced to four years at hard labor. On appeal the Supreme Court reversed the conviction on the ground that the Georgia legislation violated federal treaties and laws and was, therefore, unconstitutional. ${ }^{21}$ The defect of the Georgia statute was that it asserted over the Cherokee nation a jurisdiction that the state of Georgia did not possess. ${ }^{22}$

In an exhaustive opinion for the Court, Chief Justice Marshall analyzed the legal status of the Indian tribes. He considered the effect of the discovery of parts of America by European nations on the rights of native Indians. The discovering nation, said Marshall, had a good claim against other nations, but this claim is only "an exclusive right to purchase" 23 the land that the Indians should desire to sell. Discovery "could not affect the rights of those already in possession, either as aboriginal occupants, or as occupants by virtue of a discovery made before the memory of man."24

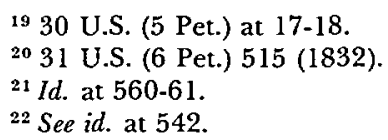
with boundaries accurately described, in which the laws of Georgia have no force, and which the citizens of Georgia have no right to enter, but with the assent of the Cherokees themselves, or in conformity with treaties, and with the acts of congress.

Id. at 561 .

${ }^{23} \mathrm{Id}$. at 544 .

24 Id. As stated by Chief Justice Marshall: "The extravagant and absurd idea that the feeble settlements made on the sea-coast, or the companies under whom they were made, acquired legitimate power by the colonial charters to govern the people, or occupy the lands from sea to sea, did not enter the mind of any man." Id. at 544-45. Of course, 
Treaties made with the Indians by the English, and later by the United States, generally stipulated that the Indians were "under the protection" of the other party. ${ }^{25}$ Such treaties, said Marshall, merely bound the Indians to the Crown (and later to the United States) "as a dependent ally, claiming the protection of a powerful friend and neighbor, and receiving the advantages of that protection, without involving a surrender of their national character."26 The treaty grant to Congress of the "sole and exclusive right of . . . managing all [the Indians'] affairs" did not constitute any surrender of self-government by the Indians. ${ }^{27}$ This was merely a grant of power to regulate the Indian trade and trade-related matters. ${ }^{28}$

The Supreme Court's decision in Williams $v . L e e^{29}$ is the modern-day endorsement of Chief Justice Marshall's approach. The Court there did not assume that all power rests in the state and federal government, but rather undertook to determine which powers had been retained by the Indian tribes from their aboriginal sovereignty or had been restored to the tribes by federal statute. Justice Black echoed the style and language of Chief Justice Marshall:

Originally the Indian tribes were separate nations within what is now the United States. Through conquest and treaties they were induced to give up complete independence and the right to go to war in exchange for

Marshall is hyperbolizing. See, e.g., Cherokee Nation v. Georgia, 30 U.S. (5 Pet.) 1, 22 (1831) (Johnson, J., concurring).

Thomas Jefferson wrote in 1792 that the American right in Indian land was merely "the sole and exclusive right of purchasing from them whenever they should be willing to sell," "a right of pre-emption." And in 1793 he noted, "I considered our right of preemption of the Indian lands not as amounting to any dominion, or jurisdiction, or paramountship whatever, . . . that the Indians had the full, undivided and independent sovereignty so long as they choose to keep it, and that this might be forever. W. WASHBURN, supra note 1 , at 56 (footnote omitted).

2531 U.S. (6 Pet.) at 551.

${ }^{26} \mathrm{Id}$. at 552. Marshall further observed that "[p]rotection does not imply the destruction of the protected." Id.

${ }^{27}$ Id. at 553-54; see 3 E. Vattel, The Law of Nations or the Principles of Natural Law bk. I, ch. I, $\S \S 5-6$ (Carnegie Institute ed., C. Fenwick transl. 1916). Originally published in 1758, Vattel's work was a textbook in the American universities in 1780, and his work is still dominant today. See W. Friedmann, The Changing Structure OF INTERNATIONAL LAW 76 (1964).

Vattel was relied on by Chief Justice Marshall in Worcester v. Georgia, 31 U.S. (6 Pet.) 515, 560-61 (1832), in support of the Indians' sovereignty, and similarly by Justice Thompson, dissenting from the denial of jurisdiction in Cherokee Nation v. Georgia, 30 U.S. (5 Pet.) 1, $52-53$ (1831) (dissenting opinion).

2831 U.S. (6 Pet.) at 553-54.

29358 U.S. 217 (1959). 
federal protection, aid, and grants of land. When the lands granted lay within States these governments sometimes sought to impose their laws and courts on the Indians. . . . The constitutionality of these laws was tested in Worcester $v$. Georgia. . . . Rendering one of his most courageous and eloquent opinions, Chief Justice Marshall held that Georgia's assertion of power was invalid. . . .

Despite bitter criticism ... the broad principles of that decision came to be accepted as law. ... O Over the years this Court has modified these principles in cases where essential tribal relations were not involved and where the rights of Indians would not be jeopardized, but the basic policy of Worcester has remained. ${ }^{30}$

The reassertion of this approach in subsequent Supreme Court cases dealing with Indian sovereignty, ${ }^{31}$ indicates that today much "remains of the notion that reservation Indians are a separate people to whom state jurisdiction . . may not extend." 32

\section{B. Indian Sovereignty and the United States Constitution}

It is not only state legislation that is inapplicable in general to Indian nations; Indian tribes have also been held to be unrestrained by the Constitution. ${ }^{33}$ The Supreme Court has apparently faced the issue squarely only once, in Talton $v$. Mayes. ${ }^{34}$ In that case a defendant convicted in the Cherokee courts attacked his conviction on the ground that his grand jury, which consisted of only five members, was insufficient under fifth amendment standards. The Supreme Court held the fifth amendment inapplicable, as it was a limitation on the federal government only. ${ }^{35}$ The Court rejected the notion that the relationship between the Indians and the federal government makes tribal powers in effect federal powers. Tribal powers were found not to be created by the Constitution, although they were "subject to its general provisions and the paramount authority of Congress." 36 Thus

${ }^{30}$ Id. at 218-19 (footnotes omitted).

${ }^{31}$ See, e.g., Mescalero Apache Tribe v. Jones, 411 U.S. 145, 148 (1973); McClanahan v. Arizona State Tax Comm'n, 411 U.S. 164, 171, 179 (1973); Organized Village of Kake v. Egan, 369 U.S. 60, 74-75 (1962).

${ }^{32}$ McClanahan v. Arizona State Tax Comm'n, 411 U.S. 164, 170 (1973).

${ }^{33}$ See generally W. WASHBURN, supra note 1, at 173-93 (1971).

${ }^{34} 163$ U.S. 376 (1896).

${ }^{35}$ Id. at 384 .

${ }^{36}$ Id. at 382-84. But see Colliflower v. Garland, 342 F.2d 369 (9th Cir. 1965) (holding that under the particular circumstances of that case, where the Indian courts had been 
the thirteenth amendment, absolutely abolishing slavery everywhere in the United States, does apply to Indians. But as Cohen puts it: "Where . . . the United States Constitution levies particular restraints upon federal courts or upon Congress, these restraints do not apply to the courts or legislatures of the Indian tribes. Likewise, particular restraints upon the states are inapplicable to Indian tribes." 37

The issue whether constitutional limitations on states apply to Indian tribes has never been passed on explicitly by the Supreme Court, but lower court decisions following Talton suggest that they do not. In Toledo v. Pueblo de Jemez ${ }^{38}$ six Protestant Pueblo Indians brought suit against their Pueblo community under the Civil Rights Act, ${ }^{39}$ alleging that its governing body and governor had subjected them to indignities, threats, and reprisals because they were not Catholic. The district court held that it lacked jurisdiction over the case because no action in violation of the federal statute was alleged. Specifically, because the tribe did not derive its governmental powers from the state of New Mexico, defendants had not acted under "color of state law." 40

Native American Church v. Navajo Tribal Council ${ }^{41}$ presented even more clearly the question of the Constitution's application to tribal governments. In that case the plaintiff sought to enjoin enforcement of a tribal law forbidding the possession or use of peyote on the Navajo reservation. Plaintiffs alleged the tribal law violated their right to free exercise of religion guaranteed by the first and fourteenth amendments. The Tenth Circuit held that the federal courts had no jurisdiction, for neither amendment binds the tribal government. The first amendment limits congressional action; and the fourteenth, state action. Because the laws of Indian tribes are neither state nor federal, the court reasoned, neither limitation can apply. The Court pointed out

established by the federal government and were still subject to its control, those courts functioned in part as federal agencies, thus giving a federal court jurisdiction to issue a writ of habeas corpus on petition of an Indian convicted and sentenced by a tribal court).

${ }^{37}$ Conen, supra note 9, at 124 (footnotes omitted). See also FEDERAL Indian Law, supra note 9 , at 400 (describing an Indian reservation as "in some respects, a civil-rights no man's land where there is no relief against tribal oppression because of the failure of Congress to make Federal civil-rights provisions . . . applicable." (footnote omitted)). Congress has acted since this statement was made, however, to change this situation to some extent. See text accompanying notes 43-46 infra.

${ }^{38} 119$ F. Supp. 429 (D.N.M. 1954).

${ }^{39} 42$ U.S.C. $\$ 1983$ (1970).

to $119 \mathrm{~F}$. Supp. at 432 .

41 272 F.2d 131 (10th Cir. 1959). 
that the Constitution is binding upon Indian nations only where that document expressly binds them or where it is made binding by treaty or by act of Congress. ${ }^{42}$

In the 1960's, as interest in civil rights increased, Congress became concerned with the lack of constitutional restraints on tribal governments. The result was the passage of the Constitutional Rights of Indians Act (the Indian Civil Rights Act of 1968). ${ }^{43}$ The Act binds all Indian tribal governments by many, but not all, of the provisions of the Bill of Rights and other sections of the Constitution. ${ }^{44}$ A highly significant aspect of the Act is simply that Congress felt it necessary; its passage acknowl-

${ }^{42}$ Id. at 134-35. The court relied on Talton v. Mayes, 163 U.S. 376 (1896), and Toledo v. Pueblo de Jemez, 119 F. Supp. 429 (D.N.M. 1954). See also Twin Cities Chippewa Tribal Council v. Minnesota Chippewa Tribe, 370 F.2d 529 (8th Cir. 1967) (fifth and fourteenth amendments not applicable to tribe).

43 Act of April 11, 1968, Pub. L. No. 90-284, 82 Stat. 77, §§ 201-03, 25 U.S.C. $\$ \$ 1301-03$ (1970). See W. WASHBURN, supra note 1, at 186-87.

\$4 25 U.S.C. $\$ 1302$ provides:

No Indian tribe in exercising powers of self-government shall-

(1) make or enforce any law prohibiting the free exercise of religion, or abridging the freedom of speech, or of the press, or the right of the people peaceably to assemble and to petition for a redress of grievances;

(2) violate the right of the people to be secure in their persons, houses, papers, and effects against unreasonable search and seizures, nor issue warrants, but upon probable cause, supported by oath or affirmation, and particularly describing the place to be searched and the person or thing to be seized;

(3) subject any person for the same offense to be twice put in jeopardy;

(4) compel any person in any criminal case to be a witness against himself;

(5) take any private property for a public use without just compensation;

(6) deny to any person in a criminal proceeding the right to a speedy and public trial, to be informed of the nature and cause of the accusation, to be confronted with the witnesses against him, to have compulsory process for obtaining witnesses in his favor, and at his own expense to have the assistance of counsel for his defense;

(7) require excessive bail, impose excessive fines, inflict cruel and unusual punishments, and in no event impose for conviction of any one offense any penalty or punishment greater than imprisonment for a term of six months or a fine of $\$ 500$, or both;

(8) deny to any person within its jurisdiction the equal protection of its laws or deprive any person of liberty or property without due process of law;

(9) pass any bill of attainder or ex post facto law; or

(10) deny to any person accused of an offense punishable by imprisonment the right, upon request, to a trial by jury of not less than six persons.

For detailed discussion of the Act, see Lazarus, Title II of the 1968 Civil Rights Act: An Indian Bill of Rights, 45 N.D.L. Rev. 337 (1969); Note, The Indian Bill of Rights and the Constitutional Status of Tribal Governments, 82 HARv. L. REv. 1343 (1969). 
edged that Indians are not bound by constitutional limitations in the absence of legislation.

In Groundhog $v$. Keeler, ${ }^{45}$ a case arising after the passage of the Act, the court held that Congress had not made the fourteenth amendment applicable to Indian tribal governments. The court's survey of the Act's legislative history led it to conclude that Congress had not bound Indians to all constitutional limitations. ${ }^{46}$ This case is consistent with the theory that all powers not taken away by the federal government are retained by the Indians.

\section{Congressional Actions Affecting the Extent of Indian Sovereignty}

Although Indian tribes are not covered by the federal constitution and although they are by their sovereign nature theoretically free from interference by the states, the federal government retains the power to expand or contract the scope of their sovereign authority. ${ }^{47}$ Some congressional legislation has restricted tribal powers, but other acts, and even the general presumption underlying some restrictive acts, have reaffirmed a theory of broad tribal power.

\section{The Treaty Power}

In Cherokee Nation v. Georgia ${ }^{48}$ and Worcester v. Georgia, ${ }^{49}$ Chief Justice Marshall concluded that Indian tribes are nations, albeit "domestic dependent" ones, which are capable of making treaties with the United States. In 1871, however, a statute was passed declaring that "no Indian nation or tribe . . shall be acknowledged or recognized as an independent nation, tribe or power with whom the United States may contract by treaty." On its face, this statute would seem to be a congressional repudiation of the basis for the Worcester decision, but a closer analysis reveals otherwise. Both the purpose and the practical effect of this departure from a strict treaty policy in dealing with Indians were to assuage the House of Representatives, who were dissatisfied with the Senate's exclusive control over Indian affairs pursuant to the treaty powers of article II, section 2 of the

4542 F.2d 674 (10th Cir. 1971).

${ }^{46} \mathrm{Id}$. at 681-82.

${ }^{47}$ See, e.g., United States v. Jackson, 280 U.S. 183 (1930); United States v. Kagama, 118 U.S. 375 (1886); United States v. Rodgers, 45 U.S. 567 (1846).

4830 U.S. (5 Pet.) 1 (1831); see text accompanying notes 16-19 supra.

49 31 U.S. (6 Pet.) 515 (1832); see text accompanying notes 20-28 supra.

${ }^{50}$ Act of Mar. 3, 1871, ch. 120, § 1, 16 Stat. 566, 25 U.S.C. $\$ 71$ (1970). Treaties already in operation were still to be honored, however. Id. 
Constitution. ${ }^{51}$ Following the 1871 Act, Indian "treaties" were made legislatively, requiring the approval of both houses of Congress. That Indian policy continued to be conducted by "agreements" between tribes and Congress as a whole, ${ }^{\mathbf{5 2}}$ suggests Congress had not really altered the extent of federal power over Indian tribes. ${ }^{53}$

\section{Early Criminal Jurisdiction}

The Court in United States $v$. Rodgers ${ }^{54}$ made clear that Congress has the power to make punishable criminal offenses committed on an Indian reservation. The precise issue in Rodgers was whether Congress had exercised this power. The Court correctly concluded that Congress had acted to assert federal jurisdiction over crimes committed on specific reservations, excluding crimes committed by Indians against Indians. ${ }^{55}$

In Rodgers, the reservation was located in "Indian Country," a term identifying territory located outside the boundaries of any state and wholly under federal and tribal control. Where Indian land was within a state's boundaries, a different result was dictated by congressional legislation in some cases. ${ }^{56}$ In United States $v$. McBratney ${ }^{57}$ the Supreme Court held that a federal court has no jurisdiction over crimes committed by whites against whites on a reservation within a state's boundaries. This did not mean that the Indian tribes had jurisdiction, but rather that the offense was cognizable only in state courts. ${ }^{58}$ Where the alleged crime was committed by a non-Indian against an Indian, however, the states were preempted by federal jurisdiction be-

51 The power to make treaties is in the President, with the advice and consent of the Senate, U.S. ConsT, art. II, \& 2.

${ }^{52}$ Comment, Tribal Self-Government and the Indian Reorganization Act of 1934, 70 Мгсн.

L. Rev. 955, 958 (1972).

${ }^{53}$ Id.

5445 U.S. (4 How.) 567, 572 (1846).

${ }^{55}$ Act of June 30, 1834, ch. 161, 4 Stat. 729, repealing Act of Mar. 3, 1817, 3 Stat. 383. See Federal Indian Law, supra note 9, at 322.

${ }^{56}$ See Act of Mar. 3, 1875, ch. 139, 18 Stat. 474 (providing "[t]hat the inhabitants of the Territory of Colorado ... are . . . authorized to form . . . a State government, . . . which State shall be admitted into the Union upon an equal footing with the original States in all respects whatsoever.") The Supreme Court held that this provision gave Colorado, as a natural attribute of state sovereignty, power to control the actions of its citizens on Indian lands located within the state. United States v. McBratney, 104 U.S. 621 (1881). Any inconsistent treaty provisions were necessarily repealed. Federal jurisdiction remained only "so far as may be necessary to carry out such provisions of the treaty ... as remain in force," i.e., those provisions essential to federal Indian policy. Id. at 624 .

57 104 U.S. 621 (1881).

${ }^{58}$ See also New York ex rel. Ray v. Martin, 326 U.S. 496 (1946); Draper v. United States, 164 U.S. 240 (1896). 
cause of the United States' interest in protecting its Indian wards.

In all the above areas, Congress had explicitly taken away the power of the Indians to control criminal justice on the reservation. In areas in which Congress did not act, however, the Indians retained their full powers. From the first statute establishing federal jurisdiction over Indian offenses ${ }^{59}$ to the present time, ${ }^{60}$ crimes committed by Indians against Indians have been left to tribal jurisdiction. This residuum of Indian sovereignty was graphically demonstrated in Ex parte Crow Dog. ${ }^{61}$

In Crow Dog, a Brule Sioux Indian was convicted in a federal court of the murder of another member of his tribe on their Dakota Territory reservation. The statute reserving to the Indians jurisdiction over crimes committed by Indians against Indians $^{62}$ was invoked by the Court to preclude the jurisdiction of the federal court. Congress, however, was unwilling to rest with this result and passed the Major Crimes Act of $1885,{ }^{63}$ making some offenses cognizable by federal courts although committed by Indians against Indians on a reservation. This legislation was soon tested and its constitutionality upheld by the Court $^{64}$ on the determination that Congress' power rested fundamentally on the sovereignty of the United States over its territory by right of ownership. ${ }^{65}$

The conclusion to be drawn is that in the criminal jurisdiction area, at least, the states may intrude into reservation affairs only when authorized by Congress. Congress has seen fit to allow the states criminal jurisdiction only in situations in which no Indian is directly involved; in such circumstances it is probable that no strong federal or Indian interest is at stake. Although the federal government has the power to intrude as much as it likes, it must do so explicitly by statute. Congress has exercised this power in only a few instances, leaving the tribal governments to protect their members in most cases of crimes committed by

${ }^{59}$ Act of Mar. 3, 1817, ch. 92, 3 Stat. 383.

60 18 U.S.C. \$ 1152 (1970); see FEDERAL Indian LAw, supra note 9, at 319-20.

61109 U.S. 556 (1883).

62 Act of Feb. 18, 1875, ch. 80. § 1, 18 Stat. 318 (repealed 1948) (now 18 U.S.C. $\S 1152(1970))$.

${ }^{63}$ Act of Mar. 3, 1885, ch. 341, § 9, 23 Stat. 362, 385, as amended, 18 U.S.C. $\$ \S 1153$, 3242 (1970). The crimes specified were murder, manslaughter, rape, assault with intent to kill, arson, burglary, and larceny. Several crimes have since been added to the orginal list. See 18 U.S.C. $\S \S 1153,3242$ (1970); Federal Indian Law, supra note 9, at 320; Comment, supra note 52 , at 957.

${ }^{64}$ United States v. Kagama, 118 U.S. 375 (1886).

${ }^{65}$ Id. at 380 . 
Indians against Indians. The area of criminal jurisdiction is a specific application of the rule articulated in Worcester $v$. Georgia: ${ }^{66}$ Indians have sovereign powers of self-government unless and until they are taken away by Congress.

\section{The Indian Reorganization Act}

Perhaps the most important piece of Indian legislation ever enacted by Congress, the Indian Reorganization Act of 1934 (the Wheeler-Howard Act), ${ }^{\mathbf{6 7}}$ recognized and legitimized existing tribal governments and encouraged Indian tribes to adopt constitutions and corporate charters. In the 258 tribal elections held under the Act, 181 tribes (129,750 Indians) voted for inclusion while 77 tribes $\left(86,365\right.$ Indians) refused its coverage. ${ }^{68}$

Although many people may have thought that the Indian Reorganization Act granted sovereign powers to Indian tribes, most of the powers existed prior to the Act and were only reaffirmed by it. ${ }^{69}$ Felix Cohen points out that in seeking this legislation the Roosevelt administration merely "accepted the logical implications of Indian self-government."70

\section{Termination}

In the 1950's the United States embarked on a policy called "termination," which aimed at assimilating the Indians into the mainstream of American society and at severing them from United States guardianship as soon as possible. ${ }^{71}$ Pursuant to this policy the states of California, Minnesota, Nebraska, Oregon and Wisconsin were given criminal and civil jurisdiction over much

66 31 U.S. (6 Pet.) 515 (1832); see text accompanying notes 12-28 supra.

67 Act of June 18, 1934, ch. 576, 48 Stat. 984, as amended, 25 U.S.C. $\$ \$ 461-79$ (1970).

${ }^{68}$ Comment, supra note 52, at 972 (citing $T$. Hass, TEN YEARs of Tribal Government under the Indian Reorganization act 3 (U.S. Ind. Serv. Tribal Rels. Pamph. 1947)). The Navajo tribe, the country's largest, rejected the Act's provisions in a referendum held pursuant to the Act. Comment, supra note 52, at 972. The tribal sovereignty of the Navajos has nevertheless been consistently recognized by the Supreme Court. See McClanahan v. Arizona State Tax Comm'n, 411 U.S. 164 (1973); Warren Trading Post Co. v. Arizona State Tax Comm'n, 380 U.S. 685 (1965); Williams v. Lee, 358 U.S. 217 (1959).

${ }^{69}$ See Comment, supra note 52 , at $970-72$. This is not to deny that the Indian Reorganization Act, 25 U.S.C. $\$ \S 461-79$ (1970), was important. Section 461 of the Act prevented Indian land from being "allotted in severalty to any Indian," thus reinforcing central tribal control over reservations, and section 463 restored other lands to tribal ownership. In addition, despite the theoretical status of the Indians, "[p]rior to the passage of the Act the Indian Service administered the reservations in complete disregard of tribal authority." W. WASHBURN, supra note 1 , at 79 .

70 Cohen, supra note 9, at 123.

${ }^{71}$ For a brief and very critical examination of this policy, see W. WASHBurs, supra note 1 , at $80-97$. 
of the Indian territory within their respective borders; this jurisdiction extended to crimes committed by and against Indians and to civil causes of action to which Indians were parties. ${ }^{72}$ Other states were given authority to acquire such jurisdiction upon their own affirmative action, ${ }^{73}$ but none has done so. In 1968, the statute was amended to require Indian consent to further elimination of their inherent tribal sovereignty. ${ }^{74}$

Although these statutory measures demonstrate the plenary power of Congress over the Indian tribes, they all necessarily recognize sub silentio that the Indians would retain the sovereign powers involved absent explicit and affirmative action by Congress. ${ }^{75}$

\section{Tribal Power to Tax}

That Indian tribes have complete power to tax both Indians and non-Indians living or doing business on Indian lands cannot be seriously questioned. This power stems from the tribes' status as sovereign entities recognized by courts since the country was born. Concurring in Worcester v. Georgia, Justice McLean noted that "[t]he power to tax is also an attribute of sovereignty." might have added that the taxing power is an essential sovereign attribute. No government stripped of the right to support itself can long retain any real sovereignty. Vattel, writing about situations in which a sovereign state has submitted itself to another more powerful state, explains that there is no single certain form

${ }^{72}$ Act of Aug. 15, 1953, ch. 505, 67 Stat. 588, as amended, 18 U.S.C. $\$ \$ 1151,1162$;

28 U.S.C. $\S \S 1331,1360$ (1970).

${ }^{73}$ Id.

7425 U.S.C. $\$ \S 1321-22$ (1970).

${ }^{73}$ In Iron Crow v. Oglala Sioux Tribe, 231 F.2d 89 (8th Cir. 1956), a case upholding the Indians' sovereign power to tax, the court relied on Felix Cohen's famous formulation of three principles of Indian sovereignty:

(1) An Indian tribe possesses, in the first instance, all the powers of any sovereign state. (2) Conquest renders the tribe subject to the legislative power of the United States and, in substance, terminates the external powers of sovereignty of the tribe, e.g., its power to enter into treaties with foreign nations, but does not by itself affect the internal sovereignty of the tribe, i.e., its power of local self-government. (3) These powers are subject to qualification by treaties and by express legislation of Congress, but, save as thus expressly qualified, full powers of internal sovereignty are vested in the Indian tribes and in their duly constituted organs of government.

CoHEN, supra note 9, at 123 (footnotes omitted) (emphasis supplied), quoted in $231 \mathrm{~F} .2 \mathrm{~d}$ at 92-93. Although Cohen's point two is not strictly accurate, the thrust of the complete formulation, liberal for its time, continues to be instructive. The conclusion of point three seems to have firmer judicial support and thus may be considered more "accurate" today than when it was written. Indeed, its essence forms the basis for much of the remainder of this Comment.

${ }^{76}$ Worcester v. Georgia, 31 U.S. (6 Pet.) 515, 591 (1832) (concurring opinion). 
of submission. Rather, according to the agreement of the contracting parties, the stronger "may either leave to the weaker state a part of its sovereignty, and merely restrict it in certain respects, or it may destroy it altogether . . .."77

The Supreme Court, beginning at least as long ago as Morris $v$. Hitchcock, ${ }^{78}$ has held that the power to tax is one of the attributes of sovereignty retained by the Indians, and this result has never been successfully challenged. The Eighth Circuit has developed the clearest line of cases in this area, and the underlying principles have only very recently been reaffirmed by the Supreme Court. ${ }^{79}$ In Buster v. Wright ${ }^{80}$ the Eighth Circuit upheld an Indian business license tax against a claim that the tax was invalid because Congress, in authorizing the entry of nonIndians into Indian territory for the purpose of doing business, had not explicitly permitted the tribes to impose license fees upon them. The court stated:

The authority of the Creek Nation to prescribe the terms upon which noncitizens may transact business within its borders did not have its origin in act of Congress, treaty, or agreement of the United States. It was one of the inherent and essential attributes of its original sovereignty. It was a natural right of that people, indispensable to its autonomy as a distinct tribe or nation, and it must remain an attribute of its government until by the agreement of the nation itself or by the superior power of the republic it is taken from it. ... $[E]$ very original attribute of the government of the Creek Nation still exists intact which has not been destroyed or limited by act of Congress or by the contracts of the Creek tribe itself. ${ }^{81}$

Iron Crow v. Oglala Sioux Tribe ${ }^{82}$ reiterated and reinforced the holding of Buster $v$. Wright. In upholding a tax on a lessee of Indian land because taxing power had never been removed by Congress, the court noted that the Indian Reorganization $\mathrm{Act}^{83}$ served to add a separate rationale for finding plenary Indian tax power on the reservation:

77 E. VATTEL, supra note 27 , bk. I, ch. $16, \S 194$.

${ }^{78} 194$ U.S. 384 (1904).

${ }^{79}$ McClanahan v. Arizona State Tax Comm'n, 411 U.S. 164 (1973).

${ }^{80} 135$ F. 947 (8th Cir. 1905).

${ }^{81} \mathrm{Id}$. at 950 .

82231 F.2d 89 (8th Cir. 1956).

${ }^{83} 25$ U.S.C. $\$ \$ 461-79$ (1970); see text accompanying notes 67-70 supra. 
Inasmuch as it has never been taken from it, the defendant Oglala Sioux Tribe possesses the power of taxation which is an inherent incident of its sovereignty.

We conclude from the original precept of tribal sovereignty and the fact that the power of the Oglala Sioux Tribe to impose the tax or license in question has not been pretermitted by any federal statute . . ., but, to the contrary, has been implemented by the Indian Reorganization Act [25 U.S.C. § 476 (1970)], that such power still exists. ${ }^{84}$

Finally, in Barta v. Oglala Sioux Tribe ${ }^{85}$ the court faced a constitutional challenge by non-Indian lessees to a tax levied by the Tribal Council upon leases. The lessees claimed that the tax violated the fifth and fourteenth amendments and that it constituted taxation without representation. The court held that the Indian tribes were not states and that the fourteenth amendment therefore had no application. ${ }^{86}$ It also rejected the fifth Amendment claim, citing Cohen for the proposition that the " 'Indian tribes ... are not creatures of either the federal or state governments," "and that, therefore, "[i] t would seem that the tribal taxing power is not subject to limitations imposed upon state or federal legislation by the Federal Constitution." "87 As to the claim of taxation without representation, the court observed that a government's ability to tax property located in its jurisdiction does not depend upon the owner's residing within its borders; in that sense a tax may be levied against persons who were not represented when the decision to tax was made. ${ }^{88}$

${ }^{84} 231 \mathrm{~F} .2 \mathrm{~d}$ at 99 . The Act was said to have given rise to the adoption by Indians of a constitution providing for the levy of taxes.

The court quoted from CoHEN, supra note 9, at 142, which states: "One of the powers essential to the maintenance of any government is the power to levy taxes. That this power is an inherent attribute of tribal sovereignty which continues unless withdrawn . . by treaty or by act of Congress is a proposition which has never been successfully disputed." 231 F.2d at 98.

8s 259 F.2d 553 (8th Cir. 1958).

${ }^{86} \mathrm{Cf}$. text accompanying notes 193-212 infra, dealing with the application of the contract clause to Indian tribes.

87259 F.2d at 557; CoHEN, supra note 9, at 181, 267.

Of course since the passage of Title II of the Civil Rights Act of 1968 this result is no longer true. See 25 U.S.C. $§ 1302$ (1970); $c f$. United States v. Mazurie, 95 S. Ct. 710, 718 n.12 (1975).

${ }^{88} 259$ F.2d at 557. The court relied on Thomas v. Gay, 169 U.S. 264, 277 (1898):

Thus it has been held that personal allegiance has no necessary connection with the right of taxation; an alien may be taxed as well as a citizen. . . . So, likewise, it is settled law that the property, both real and personal, of non- 
Recent Supreme Court decisions have reinforced the Eighth Circuit's position. In McClanahan v. Arizona State Tax Commission ${ }^{89}$ a unanimous Court noted that although the issue whether Indian powers of self-government derive from residual sovereignty or from federal statutes may be debatable ${ }^{90}$ (especially in light of the Indian Reorganization Act),${ }^{91}$ the fact is that Indians retain "the power of regulating their internal and social relations," no matter what the source. ${ }^{92}$ And in United States $v$. Mazurie,${ }^{93}$ though it was again unnecessary to decide whether the source of the power was the tribes' independent authority or congressional enactment, the Court unanimously held that the Wind River Tribes of Wyoming possessed sufficient authority to regulate the sale of liquor in Indian country, including the authority to grant and deny licenses. In that case the Indians had refused to issue a tribal liquor license to a Mr. and Mrs. Mazurie, forcing them to close their tavern. Ruling in favor of the Indians, the Court rejected a claim similar to the taxation without representation claim presented in Barta, and determined that it was irrelevant to the issue of the tribe's taxing power that the Mazuries could not become members of or participate in the tribal government. ${ }^{94}$ The presence of the Mazuries and their

residents may be lawfully subjected to the tax laws of the state in which they are situated.

${ }^{89} 411$ U.S. 164 (1973).

${ }^{90} \mathrm{Id}$. at $172 \mathrm{n} .8$.

9125 U.S.C. $\S \S 461-79$ (1970).

92411 U.S. at 173 (quoting United States v. Kagama, 118 U.S. 375, 382 (1896)).

9395 S. Ct. 710 (1975). rev'g 487 F.2d 14 (10th Cir. 1973). The holding the court of appeals was one of the most anti-tribal decisions ever handed down. The court of appeals made the following statement, which was completely rejected by the Supreme Court:

The Tribes have the usual powers of an owner of land, to the extent of such ownership, over those using their land. This power is often confused with some elements of sovereignty when large tracts are involved ....

The Arapahoe and Shoshone Tribes are very important organizations which exercise a broad tribal authority over their members. They also exercise authority as would owners of large tracts of land. . .

The tribal members are citizens of the United States. It is difficult to see how such an association of citizens could exercise any degree of governmental authority or sover eignty over other citizens who do not belong, and who cannot participate in any way in the tribunal [sic] organization. The situation is in no way comparable to a city, county, or special district under state laws. There cannot be such a separate "nation" of United States citizens within the boundaries of the United States which has any authority, other than as landowners, over individuals who are excluded as members.

487 F.2d at 19. The court then distinguished Iron Crow on the mistaken premise that it only involved tribal authority over members of the tribe. The court also failed to mention Barta, which reaffirmed Iron Crow, expressly applying it to non-Indian lessees of Indian lands.

9495 S. Ct. at 718. 
transaction of business on the reservation were viewed to be decisive. ${ }^{95}$

Indian taxation of the lessees of tribal land would be enforceable, in the first instance, in tribal courts, ${ }^{96}$ and the tribe would in most cases have substantial property of the lessee within its jurisdiction to levy against should the lessee fail to pay the tax or the judgment. Should it become necessary to go outside the Indian jurisdiction in order to enforce a tax lien, the federal courts are authorized to hear the claim. ${ }^{97}$

\section{State Power to Tax Lessees of Indian Land}

The Indians' power to tax can mean little if the states in which reservations are located are also permitted to impose taxes on the same activities. ${ }^{98}$ At least one Indian land lease makes clear that the reason the lessee required a no-tax clause ${ }^{99}$ is that it could not bear the burden of a double tax at the regional level. The economic problem of double taxation remains, however, whether or not the lease contains a no-tax clause. For the same practical reasons that state taxes diminish inexorably the rents which the Indians are able to charge ${ }^{100}$ state taxes also seriously hinder the ability of Indians to tax their lessees.

The remainder of this section will examine the power of states to tax reservation lessees. The conclusion reached here is that state taxation of mineral lessees of Indian land are generally invalid for two reasons. First, state taxes that substantially reduce

${ }^{95}$ Id. (quoting William v. Lee, 358 U.S. 217, 223 (1959)).

${ }^{96}$ See Williams v. Lee, 358 U.S. 217 (1959).

97 The claim could be brought by the United States on behalf of the Indians under 28 U.S.C. $\$ 1345$ (1970) (general federal jurisdiction over claims brought by the United States). Barta v. Oglala Sioux Tribe, 259 F.2d 553, 556 (8th Cir. 1958). Or it could be brought by the Indian tribe itself under its general right to bring suits in federal courts. Id.; Creek Nation v. United States, 318 U.S. 629, 640 (1943).

${ }^{98}$ The Supreme Court has definitively held that a state has no power to tax reservation Indians on income earned on the reservation. McClanahan v. Arizona State Tax Comm'n, 41 I U.S. 164 (1973). Thus, tribal Indians on reservations are safe from double taxation, and a portion of their income could be assessed to help run the tribal government. This tax would not be a fruitful source of tribal income, however, because of the poverty of most Indians. A more realistic goal for the tribes is to seek to raise revenues by taxing those outsiders who are using and profiting from Indian lands.

${ }^{99}$ In $\S 7(f)(i)$ of a Navajo Power Plant Lease (on file at Biddle Law Library), the lessee gives up his putative right to be free from tribal taxation if the State of Arizona either voluntarily stops taxing the lessee or if it is determined to be without power to so tax. In $\S$ 7 (f)(iii), "[t]he parties agree that the basic purpose and intent of this Section 7 (f) is that the Lessees... shall not be subject to double taxation ...."

100 Given that a lessee is willing to pay a certain total amount for a leasehold, state taxes on the income from that leasehold will serve to reduce the portion of the total received by the Indians. See Agua Caliente Band of Mission Indians v. County of Riverside, 442 F.2d 1 184, 1186 (9th Cir. 1971), cert. denied, 405 U.S. 933 (1972). 
the rental revenues of a tribe, and thus impair its ability to function, are illegal infringements on the Indians' right of selfgovernment. Second, state taxes that in any way interfere with a tribe's ability to tax or regulate its lessees are an illegal interference with the Indians' exercise of their sovereign rights to tax and to regulate.

Although the above assertions obviously overlap, they have been the subject of separate lines of cases and therefore will be discussed separately.

\section{A. Lessee Immunity from State Taxation}

1. Lessee Immunity from State Taxation Due to the Governmental Immunity of the Indian Tribe

At one time lessees of Indian lands were considered immune from state taxation under the "federal instrumentality" doctrine. The theory was that "[a] state tax on the lessee, the lease, or the profits from the lease would be 'a direct hamper upon the effort of the United States to make the best terms that it can for its wards." "101 This immunity was based primarily on the federal government's immunity from state taxation rather than on an independent tribal immunity. ${ }^{102}$ The federal instrumentality doctrine is no longer accepted by the Supreme Court as a per se rule rendering all who deal with the federal government immune from state taxation on the income from such dealings. ${ }^{103}$

In rejecting certain oil companies' claims to immunity from state taxation of income derived from activities on reservation leaseholds (claims based almost solely on the federal instrumentality doctrine), the Court in Oklahoma Tax Commission v. Texas Co. ${ }^{104}$ observed:

True intergovernmental immunity [from taxation] remains for the most part. But, so far as concerns private persons claiming immunity for their ordinary business operations (even though in connection with governmental activities), no implied constitutional immunity can rest on the merely hypothetical interferences with gov-

${ }^{101}$ Oklahoma Tax Comm'n v. Texas Co., 336 U.S. 342, 354-55 (1949) (citing Gillespie v. Oklahoma, 257 U.S. 501, 506 (1922)).

${ }^{102}$ See id. at 355. Indians have been held immune from state taxation of their reservation income. McClanahan v. Arizona State Tax Comm'n, 411 U.S. 164 (1973).

${ }^{103}$ Oklahoma Tax Comm'n v. Texas Co., 336 U.S. 342 (1949).

${ }^{104} 336$ U.S. 342 (1949). 
ernmental functions here asserted to sustain exemptions. ${ }^{105}$

The Court held the mere fact that a state tax might affect the royalty the federal government could obtain for the Indian tribe to be insufficient interference with the federal government to justify lessee immunity from tax.

The Court made clear, however, that the governmental immunity of the Indians themselves was not involved in the case: "These cases present no question concerning the immunity of the Indian lands themselves from state taxation. There is no possibility that ultimate liability for the taxes may fall upon the owner of the land."106 Furthermore, the insubstantiality of the $\operatorname{tax}$ there in question seems to have been a factor in the Court's decision; the Court found it difficult to imagine that the slight taxation by Oklahoma would impair the federal government's goal of developing the oil leaseholds for the benefit of the Indians. ${ }^{107}$

Although the Texas Co. case did not purport to deal with Indian governmental immunity, the Court was sensitive to the special problems that Indian immunity, as opposed to federal immunity, would create. As noted in United States v. Detroit, ${ }^{108}$ it was already settled by the time of Texas Co. that the indirect financial burden a state tax might place on the federal government would not by itself invalidate that tax, even if the burden were substantial. ${ }^{109}$ In Texas Co., however, the Court nevertheless emphasized the smallness of the tax involved, implicitly recognizing that a large tax could well interfere with the Indians' selfgovernment, even though it might not affect the much more wealthy federal government. ${ }^{110}$

The Detroit case was relied on by both the district court and the court of appeals in Agua Caliente Band of Mission Indians $v$. County of Riverside ${ }^{111}$ in rejecting a lessee's claim of immunity from state taxation. That claim was based mainly on the Indians' governmental immunity. The case involved a suit by the Indians themselves, seeking a ruling that holders of reservation leases which "generate[d] practically all of the income available to" the

${ }^{105} I d$. at 365 .

${ }^{106} \mathrm{Id}$. at 353.

${ }^{107}$ Id. at 351.

108355 U.S. 466 (1958).

${ }^{109} I d$. at 469 .

110336 U.S. at 351.

11306 F. Supp. 279 (C.D. Cal. 1969), aff'd, 442 F.2d 1184 (9th Cir. 1971), cert. denied, 405 U.S. 933 (1972). 
Indians, ${ }^{12}$ were immune from a state "possessory interest tax," essentially a property tax on the leaseholds. Even though this tax was a substantial one which had a considerable effect on the Indians' only source of income, and thus seriously impaired their self-sufficiency, it was upheld by both the district and appellate courts on the authority of Detroit. Dissenting, Judge Ely took sharp issue with the reasoning of the majority of the court of appeals. It was Judge Ely's view that Detroit did not address the question of a conflict between an important federal policy and state taxation of reservation lessees. ${ }^{113} \mathrm{By}$ his reasoning, Agua Caliente Band of Mission Indians not only presented a conflict between the "federal policy of protecting Indian wards"114 and state taxation, but also represented a situation in which the state taxation was an onerous burden upon the Indians. ${ }^{115}$

The approach to governmental immunity offered by Judge Ely, while emphasizing the welfare of the Indians as part of a federal policy rather than as a value in itself, ${ }^{116}$ seems much more consistent with the Supreme Court's carefully chosen language in Texas Co. than does the approach of the majority. Were Judge Ely's approach applied to Indian mineral leases, the result would be to invalidate much state taxation of lessees of Indian land. The Crow Tribe in Montana, for instance, has substantial deposits of coal on its reservation and on its most recent leases the Tribe is to receive a royalty of seventeen and one-half cents per ton. ${ }^{17}$ The state of Montana imposes on the lessees taxes substantially higher that this Indian royalty interest! ${ }^{118}$ The Montana taxes may indeed seriously impair the governmental capabilities of the Indians by denying to the tribal government a significant source of needed revenues. ${ }^{119}$ If the power to tax is not to be the power to destroy, ${ }^{120}$ Montana's taxes, which are

112306 F. Supp. at 281.

113442 F.2d at 1188 (dissenting opinion).

114 Id. at 1189 .

$115 \mathrm{Id}$. at 1188 .

${ }^{116} \mathrm{Cf}$. McClanahan v. Arizona State Tax Comm'n, 411 U.S. 164, 172 n.7 (1973).

$117 \mathrm{R}$. Barsh \& J. Henderson, supra note 4, at 8.

118 Mont. Rev. Codes ANs. $\$ 84-1302$ (Supp. 1974) assesses a tax of from twelve to forty cents per ton of coal stripped, depending upon quality. Section 84-1501 (Supp. 1974) taxes corporations at a rate of $63 / 4$ percent of their net income. Section 84-301 (Supp. 1974) and section 84-302 (Supp. 1974) make the net proceeds of a coal mine subject to local property taxes at 100 percent valuation.

119 Of course the level of state tax interference necessary to require invalidation of state taxation should be a question of fact. It is a premise of this Comment that such a showing would not in many case be a difficult matter.

${ }^{120}$ Gillespie v. Oklahoma, 257 U.S. 501, 505 (1922); Indian Territory Illuminating Oil Co. v. Olkahoma, 240 U.S. 522, 530 (1916); McCulloch v. Maryland, 17 U.S. (4 
wholly unlike the mild one per cent gross production tax at issue in Texas Co., should not be allowed to apply to lessees of the Crow tribe's land. Absent state taxation, the Indians could exact royalties from their lessees more than double what they are now able to obtain. ${ }^{121}$

The decision in Texas Co. ${ }^{122}$ has certainly not foreclosed the argument that the immunity of the Indian government from state taxation is violated by economically burdensome state taxation of lessees of Indian lands. Obviously, the economic position of each individual tribe would have to be assessed under the approach suggested here, in order to determine whether state taxation actually interferes with the functioning of the tribal government.

\section{Lessee Immunity from State Taxation}

Due to Tribal Taxation or Regulation

That a state has some power to tax lessees of Indian lands under certain circumstances cannot be gainsaid after Oklahoma Tax Commission v. Texas Co.. ${ }^{123}$ The issue whether a state can tax in a way that interferes with a tribe's exercise of tribal taxing power, however, has only very rarely been directly raised. ${ }^{124}$

Williams $v$. Lee $^{125}$ is the modern seminal case for determining questions involving tribal sovereignty. Justice Black there articulated the standard for determining the validity of state regulations dealing with non-Indians' activities on Indian reservations: "Essentially, absent governing Acts of Congress, the question has always been whether the state action infringed on the right of reservation Indians to make their own laws and be ruled by them."126 In most subsequent cases dealing with state action

Wheat.) 316 (1819); cf. Oklahoma State Tax Comm'n v. Texas Co., 336 U. S. 342 (1949);

Panhandle Oil Co. v. Knox, 277 U.S. 218, 223 (1928).

${ }^{121}$ See note 117 supra.

${ }^{122}$ See text accompanying notes 106-07 supra.

123336 U.S. 342 (1949); see text accompanying notes 104-07 supra.

${ }^{124}$ On one occasion when this issue was squarely presented, it was dismissed as an aid to litigation (which, in that case, it apparently was). Agua Caliente Band of Mission Indians v. County of Riverside, 306 F. Supp. 279 (C.D. Cal. 1969), aff d, 442 F.2d 1184 (9th Cir. 1971), cert. denied, 405 U.S. 933 (1972). The court also made a cryptic reference to Acosta v. County of San Diego, 126 Cal. App. 2d 455, 272 P.2d 92 (1954), apparently for the proposition that California Indian tribes have less sovereignty than other tribes. If the Agua Caliente Band court was suggesting that California tribes have lost their sovereign right to tax due to 28 U.S.C. $\$ 1360$ (1970), it has some support by implication from Warren Trading Post Co. v. Arizona State Tax Comm'n, 380 U.S. 685 (1965). The Acosta court, however, disclaimed any intent to deal with the taxation issue. $126 \mathrm{Cal}$. App. $2 \mathrm{~d}$ at 466,272 P.2d at 98 .

125358 U.S. 217 (1959).

${ }^{126}$ Id. at 220. 
which arguably interfered with tribal government, ${ }^{127}$ this principle has been either relied on or distinguished.

The Court has made clear in these subsequent cases that the Williams test does not apply to state regulation of activities of reservation Indians off the reservation, ${ }^{128}$ nor does it apply to state regulation or taxation of activities of reservation Indians on the reservation. ${ }^{129}$ In the former situation the states have broad power to regulate; in the latter the tribe, absent federal law to the contrary, has complete power. ${ }^{130}$ Concerning activities of non-Indians on Indian reservations, however, "both the tribe and the State could fairly claim an interest in asserting their respective jurisdictions. The Williams test was designed to resolve this conflict by providing that the State could protect its interest up to the point where tribal self-government would be affected". ${ }^{131}$ Thus, the Williams test is precisely applicable to the problem of state taxation of lessees of Indian land.

In Texas Co. there was no allegation that the state tax interfered in any way with tribal self-government or even with tribal revenues. Had the Court envisioned a Williams-type test in 1949, it would not have changed the result of the case. In Thomas $v$. Gay, ${ }^{132}$ recently cited by the Court as one of the leading cases on the exertion of state sovereignty over non-Indians active on In-

${ }^{127}$ See, e.g., Mescalero Apache Tribe v. Jones, 411 U.S. 145, 148 (1973); McClanahan v. Arizona State Tax Comm'n, 411 U.S. 164, 171, 179 (1973); Organized Village of Kake v. Egan, 369 U.S. 60, 74-75 (1962).

${ }_{128}$ Mescalero Apache Tribe v. Jones, 411 U.S. 145 (1973); Organized Village of Kake v. Egan, 369 U.S. 60 (1962).

The Mescalero opinion, in holding the Indians there taxable, seems to have completely mistaken Congress' intent in enacting 25 U.S.C. $\S 465$ (1970). Section 465 was part of the Indian Reorganization Act of 1934, 48 Stat. 985, $\S 5$. It authorized the Secretary of the Interior to acquire lands for Indians and Indian tribes, and provided that title to any such lands should be taken in the name of the United States in trust for the Indians, "and such lands or rights shall be exempt from State and local taxation."

The Court held that this language did not make the acquired lands part of the reservation, and that the tax exemption applied only to property taxes, not to taxes on Indian income from activities on the acquired lands.

On its face the Court's crabbed interpretation of the tax exemption clause in the statute seems questionable. The legislative history indicates that the Cort's underlying premise - that the acquired lands did not become part of the reservation-was wrong. The Senate debate on this issue clearly shows that land acquired pursuant to the Indian Reorganization Act for a tribe was to become a part of the reservation. As Senator Thomas stated, "section 5 of the bill provides for . . . acquiring additional lands for Indian reservations." $3 \mathrm{~W}$. Washburn, The American Indian and the United States, A DocumentaRy History 1918 (1973).

129 McClanahan v. Arizona State Tax Comm'n, 411 U.S. 164, 179 (1973).

${ }^{130} \mathrm{Id}$.

${ }^{131}$ Id. at 179.

132 I69 U.S. 264 (1898). 
dian reservations, ${ }^{133}$ the Court implied that an application of a Williams-type test to state taxation of Indian lessees might invalidate the state tax.

Thomas upheld an Oklahoma Territory property tax on non-Indian cattle grazing on Indian lands, theorizing that any effect of the tax on the tribe was "too remote and indirect to be deemed a tax upon the lands or privileges of the Indians."134 The Court in Thomas was careful, however, to differentiate the property tax on the cattle from a tax on the business of grazing or a direct tax on the income of the Indians. In this way it distinguished Pollock v. Farmers' Loan $E$ Trust Co.,${ }^{135}$ which had held that a tax on the income derived from municipal bonds clearly affected the ability of a municipality to raise money, and was therefore constitutionally invalid as "a burthen on the operations of government."136

Although the decision in Pollock ${ }^{137}$ has since been called into question, on both policy ${ }^{138}$ and constitutional ${ }^{139}$ grounds, its rationale still seems strongly applicable to state-Indian relations. State power to tax reservation activities is limited by the Williams test and by the principle of Indian sovereignty. Where state taxation of reservation activities directly interferes with effective Indian self-government, both Pollock and Thomas would seem to support invalidation of that tax.

In 1965, the Supreme Court more explicitly addressed the issue of state taxation of non-Indians on Indian reservations, but the case seemed to focus on factors other than tribal self-government. Warren Trading Post Co. v. Arizona State Tax Commission ${ }^{\mathbf{1 4 0}}$ dealt with Arizona's attempt to apply its gross receipts tax to congressionally licensed traders on the Navajo reservation. The Court, without expressly relying on the Williams test, held the tax invalid for three reasons: (1) The tax put financial burdens upon the trading post and, indirectly, upon the Indians in addition to an Indian tax prescribed by the tribe pursuant to its authority to

133411 U.S. at 168.

${ }^{134} 169$ U.S. at 273 . This direct/indirect distinction, taken from interstate commerce cases, was at least in part rejected in Texas Co., which held that the inquiry must be whether the tax effects substantial "interferences with governmental functions." 336 U.S. at 365 . But cf. id. at 353.

135157 U.S. 429 (1895).

${ }^{136} I d$. at 586.

${ }^{137}$ The Pollock decision has been codified in INT. Rev. CoDe of 1954, $\$ 103$.

${ }^{138}$ Cf. U.S. Treasury Departalent, Tax Reform Studies and Proposals 83 (1969).

${ }^{139}$ See B. Bitker \& L. Stone, Federal Income, Estate, and Gift Taxation 176 (4th ed. 1972).

140380 U.S. 685 (1965). 
charge a trader "such fees, etc., as it may deem appropriate."141 (2) "[S]ince federal legislation has left the State with no duties or responsibilities respecting the reservation Indians, we cannot believe that Congress intended to leave to the State the privilege of levying this tax." 142 (3) The state tax here in question would seriously interfere with Congress' statutory plan in an area essentially preempted by Congress. ${ }^{143}$

In its decision in McClanahan v. State Tax Commission, ${ }^{144}$ the Arizona Court of Appeals distinguished Warren Trading Post as limited to the third rationale listed above. In reversing the Arizona court's decision, the Supreme Court disagreed with this restrictive interpretation: ${ }^{145}$ "The tax ... was invalidated ... because 'from the very first days of our Government, the Federal Government had been permitting the Indians largely to govern themselves, free from state interference." "146 'This freedom from state interference, the Court went on, has likewise relieved the states of the responsibilities of regulating activity on Indian reservations. ${ }^{147}$ The Court thus read Warren Trading Post to mean (consistently with a there unstated Williams test) that where an activity by non-Indians on the reservation is regulated and taxed by the tribe, a state has no right to tax that activity.

Although the state tax seemed low in Warren Trading Post (two percent of gross income) ${ }^{148}$ and thus perhaps was not a heavy enough burden to violate the Indians' governmental immunity, ${ }^{149}$ it did interfere with the tribe's regulatory and tax powers and under that theory the substantiality of the burden was not relevant.

The Supreme Court's McClanahan decision makes the rights of the tribes and the states seem fairly clear with regard to taxation of lessees of Indian land under a Williams-Warren Trading Post test. A state tax is surely an interference with Indian tribal government when the Indians want to tax the lessees themselves but are hindered or precluded because of the state tax. For the state so to restrict the power of the tribe to tax is clearly beyond "the point where tribal self-government [is] affected."150

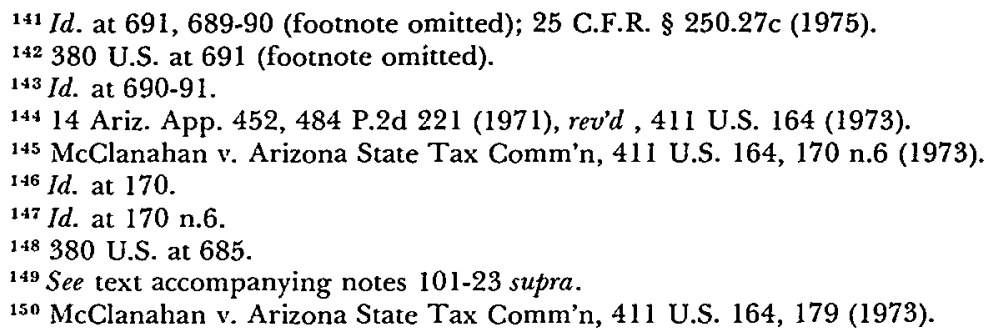


Although interference with the power of the tribe to tax is the clearest example of a state tax going beyond the bounds of the Williams test, the interference a state tax could create with the freedom of the tribe to exercise its regulatory powers may also justify invalidation of the tax. If, for example, tribes were to accept lower royalties in exchange for a lessee's promise to give preference to Indians in its hiring practices, the impact a state tax could have upon this Indian regulatory action should cause the tax to be held invalid. Thus a provision such as the one in the Navajo Tribal Code declaring that all leases granted by the tribe are not subject to any state taxes, direct or indirect, ${ }^{151}$ is presumptively valid because "[t]he assertion by the states of the power to tax leases granted by the Navajo Tribe threatens to impair the Navajo Tribe's authority to regulate businesses and industries in the Navajo Nation, through their leases . . .."152

\section{B. Exceptions to the Prohibition of State Taxation of Lessees}

\section{Areas of State Regulation}

One situation in which the states may be able to tax even in the face of a tribal tax or regulation arises when the state, and not the federal government or the tribe, is acting significantly (and, it is assumed, lawfully) to regulate an activity of nonIndians on the reservation. For example, the receipts from the small gross production tax in Oklahoma Tax Commission v. Texas $\mathrm{Co}^{153}$ were being used to fund the state system of oil regulation in which the Indian lessees participated. Such a tax seems justified under the approach offered in Warren Trading Post and McClanahan, but under this same approach a tax that raises revenue in excess of the amount needed to fund the state's regulatory system may not be justified. Except for small state taxes to finance regulatory bodies overseeing Indian lessees, it appears that most state taxation is of the latter sort.

\section{Federal Statutory Exceptions Allowing State Taxation of Lessees of Mineral Interests}

Even if state taxation would be otherwise precluded by the considerations discussed above, ${ }^{154}$ Congress could still affirmatively allow states to tax lessees of Indian lands if it wished. The

1515 Navajo Tribal Code $\$ 704$ (1972).

152 Preamble, Navajo Tribal Council Res. CMY-43-70 (May 19, 1970), following 5 Navajo Tribal Code $\$ 704$ (1972).

I53 336 U.S. 342 (1949); see notes 105-07 supra.

${ }^{154}$ See text acrompanying notes 101-52 supra. 
most recent case holding that Congress has indeed permitted state taxation of lessees of mineral interests on Indian land is Industrial Uranium Co. $v$. State Tax Commission. ${ }^{155}$ This case involved a state tax of one percent on the gross proceeds of all mining operations; ${ }^{156}$ the tax was applied to income of nonIndians derived from mining Indian lands. The court began by stating the Williams test ${ }^{157}$ and questionably implied that it was too obvious for discussion that a one percent tax on a lessee's gross proceeds does not interfere with reservation selfgovernment. ${ }^{158}$

The court then further held that "[b]y 43 Stat. 244, 25 U.S.C. $\S 398$, unalloted lands on Indian reservations may be leased .... and the production of oil and gas and other minerals from such lands may be taxed by the state in which they are located in all respects the same as production from unrestricted lands." 159 The court also held that the one percent tax applied to gross proceeds before the Indians' royalties were deducted, because section $398^{160}$ did not specifically state that royalties should be deducted before computation of the tax.

The court's holding in Industrial Uranium Co. was based on the interpretation of the same statute given by the Supreme Court in British-American Oil Producing Co. v. Board of Equalization, ${ }^{161}$ in which state taxation of a mineral lease was upheld. Some doubt about this historical interpretation is raised, however, if only because the Court in British-American Oil did not discuss and apparently did not perceive, the significance of statutory language suggesting that Congress had intended only to allow the taxation of Indian royalties deriving from mineral leases, not the taxation of the lessees of Indian lands.

Both the language and legislative history of section 398 merit closer examination. The statute provides as follows:

Unallotted land on Indian reservations [with certain exceptions] subject to lease for mining purposes ...

15595 Ariz. 130, 387 P.2d 1013 (1963).

${ }^{156}$ Ariz. Rev. Stat. ANN. $\S \S 42-1309,1310$ (1956), as amended, Ariz. Rev. Stat. ANv. §§ 42-1309, 1310 (Supp. 1975-76).

157 "State laws apply on reservations unless such application would interfere with reservation self-government or impair a right granted or reserved by federal law." 95 Ariz. at 130, 132-33, 387 P.2d at 1013-14 (1963) (citing Organized Village of Kake v. Egan, 369 U.S. 60, 75 (1962)).

15895 Ariz. at $132-33,387$ P.2d at 1015.

159 Id. at 133,387 P.2d at 1015.

16025 U.S.C. $\$ 398$ (1970).

161299 U.S. 159 (1936). 
under section 397 of this title may be leased . . . for a period of not to exceed ten years, and as much longer as oil or gas shall be found in paying quantities. ... Provided, That the production of oil and gas and other minerals on such lands may be taxed by the State in which said lands are located in all respects the same as production on unrestricted lands, and the Secretary of the Interior is authorized and directed to cause to be paid the tax so assessed against the royalty interests on said lands: Provided, however, That such tax shall not become a lien or charge of any kind or character against the land or the property of the Indian owner. ${ }^{162}$

It would seem strange for a statute authorizing a tax on lessees of Indian land to order that the tax be paid out of the royalty interest of the Indians. ${ }^{163}$

When the proviso dealing with taxability was added to section 398, a short debate followed during which Representative Crampton remarked: "[T] $]$ he important provision is that with reference to the taxation of the royalties, the Indians' income, from oil development." ${ }^{164}$ And in reference to an identical

16225 U.S.C. § 398 (1970). 25 U.S.C. § 397 (1970) states:

Where lands are occupied by Indians who have bought and paid for the same, and which lands are not needed for farming or agricultural purposes, ... the same may be leased by authority of council speaking for such Indians, for a period not to exceed .... ten years for mining purposes. . . , subject to the approval of the Secretary of the Interior.

The "bought and paid for" language is

by uniform administrative practice and by judicial decision ... construed as not confined to lands aquired by Indians through the payment of a consideration in money, but equally including lands reserved for Indians in return for a cession or surender by them of other lands, possessions, or rights.

British-American Oil Producing Co. v. Board of Equalization, 299 U.S. 159, 164 (1936) (dictum) (footnote omitted).

Reservations were and are of two classes. "Bought and paid for" reservations are those which the Indians obtain in a trade, typically one whereby they would give up much of their land in exchange for the right to keep the rest of it, along with a promise of friendship and support from the federal government. Thus, even though the Indians received no new land in a deal such as this, the land they retained would be considered "bought and paid for." All treaty and almost all legislatively established reservations are considered "bought and paid for."

Executive-order reservations did not require that Indians give up anything. The typical one, is illustrated by the situation of the Navajos, whose treaty reservation of three million acres was extended by executive order to thirteen million acres. See 68 CoNG. REC. 4579 (1927) (remarks of Representative Hayden).

Executive-order reservations are covered by sections 398 a-e rather than by section 398. See note 175 infra.

${ }^{163}$ See A. McLANE, supra note 2, $\S 179,182$.

${ }^{164} 65$ CoNG. REC. 6844 (1924) (remarks of Representative Crampton). 
proviso in another bill dealing only with unallotted lands in the Kaw reservation in Oklahoma, Senator Curtis said: "The amendment [adding the proviso] simply provides that the royalties derived from the leasing of the oil land shall be taxable to the State without a lien upon the land."165 The Court in British-American Oil made no attempt to explain the import of the royalty tax language, although that language stands out in the admittedly brief legislative history of section 398.

In Oklahoma Tax Commission v. Texas Co. ${ }^{166}$ the Court agreed that "Congress' purpose in enacting . . . statutes [whose royalty tax language was similar to that of section 398] was the removal of the immunities of the Indians themselves" in response to the "favorable economic position of the particular Indians" there involved.167 The Court then added, without discussion, that "[t]he resulting removal of the immunity of private lessees of those Indian lands was an incidental effect of this legislation." 168

British-American Oil nowhere referred to the removal of lessee's immunity as an incidental effect, but rather made clear that such immunity was dissolved directly by a similarly phrased statute. Although offhandedly and through dictum, the Court in Texas Co. seems to have faced for the first time the obvious difference between authorizing taxation of Indian royalties and authorizing taxation of reservation lessees. ${ }^{169}$ Texas Co.'s formu-

165 Id. 6867 (remarks of Senator Curtis).

166336 U.S. 342 (1949).

${ }^{167}$ Id. at 366-67. But of. 68 CoNg. REc. 4578 (1927) (remarks of Representative Carter): "To say that the Navajo Indian is wealthy is to make a man laugh who knows anything about their condition."

168336 U.S. at 367 (emphasis supplied).

${ }^{169}$ One of the statutes referred to by the Court. 336 U.S. at $366 \mathrm{n} .40$, provides in part:

That the production of oil and gas and other minerals on such restricted lands may be taxed by the State of Oklahoma in all respects the same as production on unrestricted lands, and the Secretary of the Interior is hereby authorized and directed to cause to be paid the tax so assessed against the royalty interests of the respective Indian owners in such production from the royalties or from any other individual Indian funds held under his supervision belonging to the Indian owner of the land. . . . Act of May 27, 1924, ch. 200, § 1, 43 Stat. 176. However, 45 Stat. 476 is worded somewhat differently, providing in part:

That all minerals ... from restricted allotted land of members of the Five Civilized Tribes in Oklahoma ... shall be subject to all State and Federal taxes of every kind and character the same as those produced from lands owned by other citizens of the State of Oklahoma; and the Secretary of the Interior is hereby authorized and directed to cause to be paid ... the tax or taxes so assessed against the royalty interest of the respective Indian owners in such oil, gas, and other mineral production. Act of May 10, 1928, ch. 517, $\$ 3,45$ Stat. 495.

If the point made by the Court applies to these provisions, it necessarily applies to section 398 . 
lation of the issue in this manner raises questions about the continued validity of British-American Oil.

In stating that lessee immunity was removed incidentally, the Court in Texas Co. may have thought that to tax Indians on their royalty income from mineral production without taxing the private lessees would protect the private party more than the Indian "ward." This conclusion, however, cannot withstand economic analysis because of the significant effect which a heavy gross production tax against lessees might have on the reservation leasing activities.

At the time the royalty tax provisos were put into divers leasing statutes, ${ }^{170}$ lessees of Indian land had immunity from state taxation because they were still considered instrumentalities of the federal government. ${ }^{171}$ Under this doctrine the federal purpose which would potentially be disrupted by a state tax on lessees is the Government's interest in negotiating "the best terms it can get for its wards." A state tax on the Indians themselves would not affect the ability of the Government to negotiate leases. ${ }^{172}$ Thus, it is possible that Congress wished to allow the states to gain some revenues by taxing the Indians, but also to maintain the lessees' immunity from tax in order to protect the federal government's interest in negotiating the best possible lease agreements. This makes more practical sense when one considers that Congress may have been under the impression that the Indians affected by section 398's proviso were wealthy. ${ }^{173}$ By permitting a tax on royalties only, the federal government would facilitate any state interests in taxing wealthy Indians and would still keep a guardian's grasp of the economic development of the reservations. ${ }^{174} \mathrm{~A}$ tax on reservation lessees,

170 Note 169 \& text accompanying note 162 supra.

${ }^{17}$ See Choctaw, O. \& G.R.R. v. Harrison, 235 U.S. 292 (1914); see text accompanying notes 101-52 supra.

${ }^{172} \mathrm{Cf}$. Choteau v. Burnet, 283 U.S. 691 (193I) (holding that once royalties have been distributed to the Indians they are no longer exempt from taxation as federal instrumentalities).

${ }^{173}$ See note 167 supra \& accompanying text.

${ }^{174}$ The Court's reasoning in Texas Co. may have been that without Indian immunity from taxation the legal basis for lessee immunity collapsed. In other words, if the reason the states could not tax the lessees was that such a tax would ultimately be a burden on the Indians, then to remove the immunity of the latter must necessarily destroy the immunity of the former. This argument, though attractive on its face, fails to note that the federal instrumentality doctrine was based on the federal government's immunity and on the lessees' dealings with the federal government.

Absent a fully viable instrumentality doctrine, the lack of federal authoriztion of a state tax on reservation lessees is significant (1) to the extent it may be disruptive of Indian self-government, and thus in a broad sense disruptive of general Indian immunity (in areas other than royalty taxation where immunity has been foreclosed); and (2) to the 
if excessive, could detrimentally affect production on Indian land, and thus depress economic activity.

Inasmuch as the possibility of taxation exclusively of Indian royalty interests was not even addressed in British-American Oil, although the issue is fairly raised by the statutory language, British-American Oil should not be considered a decisive interpretation. Certainly it may be said that the Texas Co. theory that taxation of lessees flows "incidentally" from taxation of Indians' royalties is without apparent justification. Section 398 deserves close reexamination before it is interpreted as granting to states the power to tax reservation lessees. ${ }^{175}$

extent it is disruptive of Indian taxation or an Indian regulatory purpose. Text accompanying notes 101-52 supra.

${ }^{175}$ Section 398c, dealing with executive-order reservations, seems on its face to mandate a different result for these reservations. It states:

Taxes may be levied and collected by the State or local authority upon improvements, output of mines or oil and gas wells, or other rights, property, or assets of any lessee upon lands within Executive order Indian reservations in the same manner as such taxes are otherwise levied and collected, and such taxes may be levied against the share obtained for the Indians as bonuses, rentals, and royalties, and the Secretary of the Interior is hereby authorized and directed to cause such taxes to be paid out of the tribal funds in the Treasury: Provided, That such taxes shall not become a lien or charge of any kind against the land or other property of such Indians.

25 U.S.C. $\$ 398 \mathrm{c}$ (1970). Although this statute seems to give states plenary authority to tax mineral lessees on executive-order reservations, this was not the intent of Congress. The pupose of this provision was to eliminate the federal instrumentality doctrine with regard to executive-order reservations, but not necessarily to give the states unrestricted power to tax. Thus, as stated in H.R. REP. No. 1791, 69th Cong., 2d Sess. 4 (1927):

The terms relating to taxation used in section 3 [398c] of the bill are taken from the proviso to section 32 of the general leasing act (41 Stat. 450) which has been construed by the Supreme Court in the case of Mid-Northern Oil Co. v. Walker, Treasurer of the State of Montana, as follows: "We think that the proviso plainly discloses the intention of Congress that persons and corporations contracting with the United States under the [general leasing] act should not for that reason be exempt from any form of State taxation." (emphasis supplied).

Thus, section 398c anticipates Texas $C o$. insofar as executive-order reservations are concerned. It does not foreclose, however, factors other than the federal instrumentality doctrine from acting to limit the power of states to tax lessees of Indian mineral interests. Text accompanying notes 101-52 supra. Executive-order reservations should not be treated any differently from "bought and paid for" reservations for purposes of state taxation.

Because Congress' purpose in enacting sections 398a-e was "to put an Executiveorder reservation on the same footing with a treaty [or legislative] reservation," 68 Cong. REc. 4579 (1927)(remarks of Representative Hastings); id. $4569-70$ (remarks of Representative Hayden), it might seem anomalous to interpret the somewhat ambiguous words of 25 U.S.C. $\$ 398$ differently from the seemingly clear language of section $398 \mathrm{c}$. The legislative history, shows, however, that Congress was intentionally withdrawing the protection of the federal instrumentality doctrine from lessees on executive-order reservations in enacting section 398c, something it never discussed when it enacted section 398. This distinction was not due to any change of heart by Congress between 1924 and 1927, but rather to the influence of two groups of congressmen who for quite different reasons were opposed to tax-free status for lessees on executive-order reservations. One 


\section{Indian Sovereignty and No-Tax Glauses: Contracting Away the Taxing Power}

It has been put forth that the Indian tribes have, as sovereigns, the power to tax anyone doing business on their reservations, and that absent express congressional authorization the states should generally not be allowed to tax heavily the operations of non-Indians on reservations. As noted above, ${ }^{176}$ however, leases of Indian land made between tribal councils and outside mining, oil, or power interests often contain a clause declaring that royalties provided in the lease are in lieu of any taxes and that the Indians covenant not to tax the outsiders in any way for the term of the lease. Obviously this is an important safeguard for any lessee given the widely held assumption that lessees are subject to state taxation. If the arguments presented above are accepted, however, and the states are forbidden to levy all but modest taxes on lessees, the basic purpose of the no-tax clauses - to insulate the non-Indian interests from taxation by both state and tribal governments-would no longer exist. ${ }^{177}$

In any case, if a tribal government were to attempt to tax lessees despite the no-tax agreements, resistance could be expected. As a result of the unique status of Indian tribes, however, the lessees might well be left without any remedy against the lessor tribe other than termination of the entire contract.

group felt that while Indians may have been clearly entitled to their treaty reservations, executive-order reservations were a gift to the Indians by the federal government (specifically the Executive branch) in derogation of the prerogatives of Congress and at the expense of the states. The purpose of sections 398a-e was to extend to the Indians, in addition to the surface rights of hunting, agriculture, and occupancy they already enjoyed on executive-order reservations, the right to sell the mineral interests in these reservations for their own benefit. By permitting state power to tax the income from these mineral interests which were transferred to the Indians, section 398c probably served to satisfy many of those who were opposed to a "complete giveaway." See generally 68 Cong. Rec. 4569-81 (1927).

Another group of congressmen was opposed to opening executive-order reservations to mineral leasing because it felt this to be an unwarranted boon to the oil and coal companies. Id. $4576-78$. Section $398 \mathrm{c}$ served to assuage their opposition by providing that these companies would not enjoy the further advantage of immunity from state taxes under the federal instrumentality doctrine.

Barsh and Henderson argue that notwithstanding sections 398 and $398 \mathrm{c}$, see note 175 supra, the states cannot tax either the Indians or their lessees because "any State tax which substantially interferes with the collection of tribal tax or the application of the proceeds of trible [sic] production to tribal welfare, would be in conflict with the most recent federal law." R. Barsh and J. Henderson, supra note 4, at 7-8; $f$. Comment, supra note 1 . This conslusion, that sections 398 and $398 c$ have been implicitly repealed, seems unnecessary, however, since Congress had no intention of having states use these sections in derogation of Indian sovereignty.

176 See note 99 supra \& accompanying text.

177 See text accompanying notes 98-99 supra. 
This result, which seems startling at first, follows logically from either of two attributes of sovereignty retained by the Indians: (1) tribal sovereign immunity, and (2) the inalienability of sovereign powers, such as the tax and police powers, especially in light of the Indians' freedom from the restrictions of the United States Constitution.

\section{A. The Right of a Tribe to Repudiate Contracts}

1. The Absence of a Forum to Challenge Repudiation: Tribal Sovereign Immunity

If a tribe were to pass a law taxing lessees of its land who had been promised freedom from such taxation, the tribe would clearly be in breach of contract. The difficult question is whether this conduct could be challenged by a lessee. Lessee could not sue in a tribal court, which would be bound to enforce its tribe's laws unless they violated the tribe's constitution (if one exitsed). Indeed, lessee might simply be barred from suing in the tribal court because a sovereign can control access to its courts as it wishes. ${ }^{178}$ Although the matter is not free of all doubt, there does not appear to be a remedy for the lessee in state or federal court either.

The case of Williams $v$. Lee ${ }^{179}$ seems controlling on the question whether the tribe could be sued in state court. This case considered the related issue whether an Arizona resident could maintain a suit in state court on a debt due from a reservation Indian. The Supreme Court looked to the criminal jurisdiction precedents discussed above ${ }^{\mathbf{1 8 0}}$ and concluded that Arizona's assertion of jurisdiction was an interference with tribal self-government. ${ }^{181}$ Congress had not acted to give Arizona jurisdiction over the Indians. The standard applied by the Court (whether the state action would "infringe on the right of the Indians to govern themselves" ${ }^{182}$ ) applies even more clearly to a suit against a tribe for breach of contract.

In the absence of a specific provision giving consent on behalf of the Indians, a lessee's access to federal court for suit against the tribe also seems foreclosed. ${ }^{183}$ Justice Brandeis inti-

\footnotetext{
${ }^{178}$ Thebo v. Choctaw Tribe, 66 F. 372, 375 (8th Cir. 1895).

179358 U.S. 217 (1959).

${ }^{180}$ See text accompanying notes 55-66 supra.

181358 U.S. at 222.

182 Id. at 223.

${ }^{183}$ See Federal Indian Law, supra note 9, at 491-95.
} 
mated this to be the case in Turner $v$. United States, ${ }^{184}$ in which the decision that the Creek Indian tribe could not be sued was based on the lack of a substantive right rather than a lack of jurisdiction over the tribe. ${ }^{185}$ The Supreme Court faced the issue more directly in United States $v$. United States Fidelity $\xi^{\circ}$ Guaranty Co. ${ }^{186}$ In that case, the lower court had granted judgment on a counterclaim against the United States, which had brought suit on behalf of the Indians for money due on a surety's bond guaranteeing lease royalties. Although the tribe had dissolved prior to the suit, the Supreme Court reversed, holding that the public policy that had exempted both sovereignties (the tribe and the United States) from suit without consent continued to operate after dissolution. ${ }^{187}$ Lower federal courts have recognized the significance of this decision and have held that the Indian tribes have sovereign immunity coextensive with that of the United States. ${ }^{188}$

Leaving a lessee who contracts with an Indian tribe without a remedy for a breach may seem harsh, but the doctrine of immunity leads logically to this conclusion. In Hans $v$. Louisiana ${ }^{189}$ the Supreme Court, concluding that the suability of a state without its consent was "unknown to the law," quoted the words of Daniel Webster:

"The security for state loans," he said, "is the plighted faith of the State as a political community. It rests on the same basis as other contracts with established governments, the same basis, for example, as loans made by the United States under the authority of Congress; that is to say, the good faith of the government making the loan, and its ability to fulfill its engagements."190

It might be argued, however, that the Indian tribes have implicitly consented to be sued in a breach of contract situation, or that Congress has implicitly consented for them. Yet the recent Supreme Court case of Employees of the Department of Public

184248 U.S. 354 (1919) (dictum).

${ }^{185} \mathrm{Id}$. at 358 . The suit in Turner was for damages arising out of the destruction of a non-Indian's property by a mob of Creeks, in which certain Creek tribal officers participated.

${ }^{186} 309$ U.S. 506 (1940).

${ }^{187} \mathrm{Id}$. at 512.

${ }^{188}$ Hamilton v. Nakai, 453 F.2d 152 (9th Cir. 1971), cert. denied, 406 U.S. 945 (1972) (dictum); see Twin Cities Chippewa Tribal Council v. Minnesota Chippewa Tribe, 370 F.2d 529 (8th Cir. 1967); Barnes v. United States, 205 F. Supp. 97 (D. Mont. 1962).

${ }^{189} 134$ U.S. 1 (1890). 1839).

${ }^{190} I d$. at 16 (quoting Letter from Daniel Webster to Baring Bros. \& Co., Oct. 16, 
Health $\mathcal{F}^{2}$ Welfare v. Department of Public Health $\xi$ Welfare, ${ }^{191}$ held that congressional removal of state immunity (where Congress has such power under the commerce clause) should not be inferred from silence, but must be explicitly stated. ${ }^{192}$ And Congress has never explicitly withdrawn the Indians' sovereign immunity in this class of cases.

Of course, allowing sovereign immunity to insulate an Indian tribe against suit for a breach of contract will, if the Indians choose to exercise it, impair their credibility for future dealings with non-Indians. But this does not indicate that the approach should not be taken; rather, it cautions against abuse. Realizing the possible adverse ramifications of evading a contract by asserting immunity, a tribe will probably not cause a breach unless the contract's terms are so obviously repugnant to the Indians' interest that a prospective party to a future contract could not expect a similar bargain to result from fair and equitable negotiation.

\section{The Inalienability of Sovereign Powers}

Assuming an aggrieved lessee can overcome the hurdle of Indian sovereign immunity and make his way into federal court, he may still face considerable problems: The tribe may assert that the no-tax clause is void because it purports to contract away a power inherent in the tribe's sovereign nature.

\section{a. The Taxing Power}

The general rule is that a sovereign body cannot legislate in such a way as to bind a future legislature. Cooley, in his Constitutional Limitations, wrote:

To say that the legislature may pass irrepealable laws, is to say that it may alter the very constitution from which it derives its authority; since, in so far as one legislature could bind a subsequent one by its enactments, it could in the same degree reduce the legislative power of its successors; and the process might be repeated, until, one by one, the subjects of legislation would be excluded altogether from their control, and the constitu-

191411 U.S. 279 (1973). (1964).

${ }^{192}$ Id. at 287 (Marshall, J., concurring); $c f$. Parden v. Terminal Ry., 377 U.S. 184

Although in the case of states of the Union this careful approach is based on the eleventh amendment, the federal policy of recognizing and encouraging Indian sovereignty should mandate application of the same approach to Indian tribes. See notes 72-75 supra \& accompanying text; $c f$. United States v. United States Fidelity \& Guar. Co., 309 U.S. 506 (1940). 
tional provision that the legislative power shall be vested in two houses would be ... rendered ineffectual. ${ }^{193}$

However, the general rule is modified, Cooley continues,

by an important provision of the Constitution of the United States, forbidding the States passing any laws impairing the obligation of contracts. Legislative acts are sometimes in substance contracts between the State and the party who is to derive some right under them, and they are not the less under the protection of the clause quoted because of having assumed this form. ... And it now seems to be settled . . . that a State, by contract to that effect, based upon a consideration, may exempt the property of an individual or corporation from taxation for any specified period, or even permanently. ${ }^{194}$

The state and federal courts have accepted and recognized both of these important propositions. ${ }^{195}$

Although the general rule against irrepealable legislation is applicable to Indian tribal governments, the specific exception grounded in the contract clause is not. As has been shown above, Indian tribes are not bound by constitutional limitations unless Congress clearly and explicitly acts to bind them. ${ }^{196}$ And Congress has thus far chosen not to do so with regard to a tribe's power to impair the obligation of contracts. The Indian Civil Rights Act of $1968^{197}$ has been correctly held not to bind tribes

1931 T. Cooley, Constitutional Limitations 247 (8th ed. 1927) (footnote omitted). Though Cooley is referring to state power, the principle applies with equal force to any sovereign government.

Cooley continues:

"Acts of Parliament," says Blackstone, "derogatory from the power of subsequent Parliaments, bind not ... . Because the legislature, being in truth the sovereign power, is always of equal, always of absolute authority; it acknowledges no superior upon earth, which the prior legislature must have been if its ordinances could bind a subsequent Parliament. And upon the same principle, Cicero, in his letters to Atticus, treats with a proper contempt these restraining clauses which endeavor to tie up the hands of succeeding legislatures. "When you repeal the law itself,' says he, 'you at the same time repeal the prohibitory clause which guards against such repeal." "

Id. 247-48 (quoting 1 W. Blackstone, Commentaries *90).

${ }^{194}$ Id. 248.

195 See, e.g., Indiana ex rel. Anderson v. Brand, 303 U.S. 95 (1938); Stone v. Mississippi, 101 U.S. 814 (1890); New Jersey v. Yard, 95 U.S. 104 (1877); Paterson v. Dempsey, 152 Conn. 431, 207 A.2d 739 (1965); Thomas v. Daughters of Utah Pioneers, 114 Utah 108, 197 P.2d 477 (1948), appeal dismissed, 336 U.S. 930 (1949); $c f$. Arkansas State Highway Comm'n v. Butler, 105 F.2d 732 (8th Cir. 1939).

${ }^{196}$ See generally text accompanying notes $33-46$ supra.

${ }^{197}$ Note 47 supra. 
to limitations not specified therein. ${ }^{198}$ Thus it would seem that an Indian tribe can repeal any legislation it has the power to make.

\section{b. The Police Power}

Even if the contract clause were held applicable to an Indian tribe, a reasonable tax on lessees would not so impair the obligation of contract as to be unconstitutional. Although bound by the contract clause, a state cannot bargain away its police power. ${ }^{\mathbf{1 9 9}}$ The question at hand is whether no-tax clauses in Indian leases constitute such a surrender of the police power.

In Stone $v$. Mississippi, ${ }^{200}$ the state had granted a lottery company a twenty-five year charter under which to conduct its business. Within that twenty-five-year period Mississippi amended its constitution to prohibit the legislature from authorizing lotteries, and passed anti-lottery legislation. Chief Justice Waite, speaking for the Court, said a state could make "irrevocable grants of property and franchises" only if they did not "impair the supreme authority to make laws for the right government of the State ...."201 In a general discussion, Chief Justice Waite wrote:

We have held, not, however, without strong opposition at times, that the [contract] clause protected a corporation in its charter exemptions from taxation. While taxation is in general necessary for the support of government, it is not part of the government itself. Government was not organized for the purposes of taxation, but taxation may be necessary for the purposes of government. As such, taxation becomes an incident to the exercise of the legitmate functions of government, but nothing more. No government dependent on taxation for support can bargain away its whole power of taxation, for that would be substantially abdication. All that has been determined thus far is, that for a consideration it may, in the exercise of a reasonable discretion, and for the public

${ }^{198}$ Groundhog v. Keeler, 442 F.2d 674 (10th Cir. 1971).

${ }^{199}$ E.g., El Paso v. Simmons, 379 U.S. 497 (1965); Veix v. Sixth Ward Bldg. \& Loan Ass'n, 310 U.S. 32 (1940); Home Bldg. \& Loan Ass'n v. Blaisdell, 290 U.S. 398 (1934); Stephenson v. Binford, 287 U.S. 251 (1932); Union Dry Goods Co. v. Georgia Pub. Serv. Corp., 248 U.S. 372 (1919); Pennsylvania Hosp. v. Philadelphia, 245 U.S. 20 (1917); Walla Walla v. Walla Walla Water Co., 172 U.S. 1 (1898) (dictum); Stone v. Mississippi, 101 U.S. 814 (1879).

200101 U.S. 814 (1879). (1866)).

${ }^{201}$ Id. at 817 (quoting Metropolitan Board of Excise v. Barrie, 34 N.Y. 657, 667 
good, surrender a part of its powers in this particular. ${ }^{202}$

Total surrender of taxing power may in this way amount to a surrender of the police power. A state cannot be held to have bargained away so much of its tax power that it is left unable to carry on its functions as a government.

So long as an exercise of the police power bears a substantial relationship to a legitimate state purpose, it makes no difference that the legislation has the effect of modifying or even abrogating contracts already in effect. In Stephenson v. Binford, ${ }^{203}$ involving state regulation of minimum shipping rates, the Court ruled that the relevant contracts "are to be regarded as having been made subject to the future exercise of the constitutional power of the state."204

Similarly, legislation enacted during the Great Depression limiting the foreclosure rights of mortgagees of real property withstood a contract clause challenge in Home Building ES Loan Association v. Blaisdell. ${ }^{205}$ Though the Court hedged its decision with findings that the state had done its best to safeguard the interests of the mortgagees, its language was expansive:

Not only are existing laws read into contracts in order to fix obligations as between the parties, but the reservation of essential attributes of sovereign power is also read into contracts as a postulate of the legal order. The policy of protecting contracts against impairment presupposes the maintenance of a government by virtue of which contractual relations are worth while,-a government which retains adequate authority to secure the peace and good order of society. This principle of harmonizing the constitutional prohibition with the necessary residuum of state power has had progressive recognition in the decisions of this Court. ${ }^{206}$

If a government were in extremis, it is hard to envision that this language and the underlying analysis would not permit it to levy reasonable taxes in spite of a contractual promise not to do so. To prohibit such taxes would be to allow the destruction of the government itself, rendering meaningless the protection against impairment of contracts.

${ }^{202} I d$. at 820 (dictum) (emphasis supplied).

203287 U.S. 251 (1932).

${ }^{204} \mathrm{Id}$. at 276.

205290 U.S. 398 (1934).

${ }^{206}$ Id. at 435. 
Blaisdell, although addressing only temporary emergency legislation, has not been read narrowly and was held to control in Veix v. Sixth Ward Building $\mathcal{E}^{2}$ Loan Association, ${ }^{207}$ which involved a permanent New Jersey statute changing the rights of shareholders of building and loan associations. The Supreme Court, in affirming the state's legislation, read Blaisdell as having reasserted the "rule that all contracts are made subject to the paramount authority" of the state to "safeguard vital interests of its people." 208 A state's authority "is not limited to health, morals and safety. It extends to economic needs as well."209

The foregoing analysis has sought to show that under some circumstances contracting away state tax power can be equivalent to contracting away the police power. Inasmuch as a state may disregard existing contracts if necessary for a reasonable exercise of the police power, those contractual limitations on taxing which amount to limitations on the police power cannot be absolutely binding on a state. It follows that a tribe may, if necessary, disregard no-tax clauses in leases in order to exercise its police powers to provide for the welfare of its people. This Comment does not undertake to prove that any particular tribe could meet this burden today, but merely seeks to demonstrate that the contract clause, even if held applicable to Indian tribes, would not be an absolute bar to tribal claims that no-tax clauses may be unenforceable.

\section{B. The Due Process Argument Against Allowing Repudiation}

One interesting argument could be made against the power of a tribe to repudiate a no-tax clause. It could be asserted that a violation of a no-tax clause deprives the lessee of a property interest in contravention of the Indian Givil Rights Act, which does prohibit a tribe from taking property without compensation. ${ }^{210}$

Even if the lessees are said to have property interests in a no-tax clause, such interests would still not be absolute. Some of the cases cited above in which contract clause violations were alleged also involved allegations that the states were taking property without compensation and hence without due process of law. ${ }^{211}$ The same analysis used to sustain the legislation under the contract clause was used in the due process context: neither

207310 U.S. 32 (1940).

208 Id. at 38.

${ }^{209} I d$. at 38-39 (footnotes omitted).

21025 U.S.C. § 1302(5) (1970); see note 46 supra.

${ }^{211}$ Stephenson v. Binford, 287 U.S. 251 (1932); Union Dry Goods Co. v. Georgia Pub. Serv. Corp., 248 U.S. 372 (1919). 
clause restricts a government from regulating property in the public interest. Furthermore, a reasonable tax, although impairing the value of a lease, does not destroy the lease and would not really constitute a taking. An analogous question is presented by ordinary zoning regulation which may undeniably impair property values but which nonetheless has been held not to involve a taking without compensation. ${ }^{212}$

\section{Conclusion}

An Indian tribe should be permitted in some circumstances to repudiate a no-tax clause, even though the lessee would be left without a remedy. If the contract clause is not applicable to a tribe, it could apparently repudiate at will, though this would likely not be done for fear of impairing the tribe's credibility. ${ }^{213}$ If the contract clause or the due process clause is held to apply to tribal government, repudiation should still be possible, at least if a showing can be made that a tax is reasonably necessary to enable a tribe to carry out its functions as a sovereign governmental body.

\section{Tribal Rights Against the United States as Trustee}

Even if all the arguments advanced in this Comment so far are rejected, an Indian tribe should be able to recover damages from the United States for not acting in the best interests of the tribe in negotiating leases, or in approving unfavorable leases made by the tribes themselves. Ever since Cherokee Nation $v$. Georgia"14 held Indian tribes to be "domestic dependent nations,"215 the United States has been held to have a special relationship to the tribes. That case described the Indians as existing "in a state of pupilage. Their relation to the United States resembles that of a ward to his guardian."216 Though this may be a somewhat simplistic description of a complex, indeed a unique relationship, ${ }^{217}$ a special relationship of dependency on the United States undoubtedly does exist and has been recognized by the courts repeatedly. ${ }^{218}$ Out of this relationship the

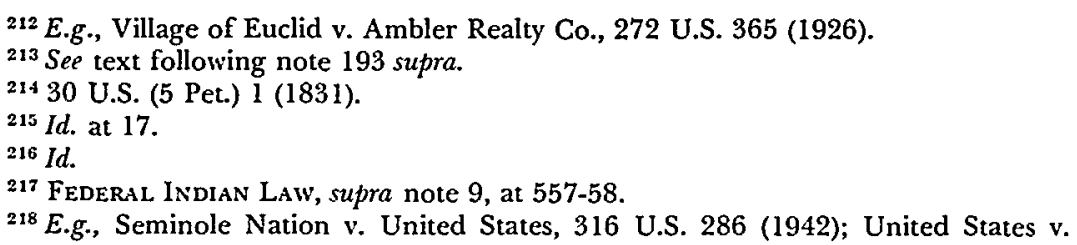
Shoshone Tribe, 304 U.S. 111 (1938); Carpenter v. Shaw, 280 U.S. 363 (1930); Manchester Band of Pomo Indians v. United States, 363 F. Supp. 1238 (N.D. Cal. 1973); Navajo 
United States acquires a special responsibility that may be accurately described as a fiduciary duty.

\section{A. Ability of Indian Tribes to Sue the United States for a Breach of Fiduciary Duty}

Before discussing the nature of the duty owed by the United States to the Indian tribes, the question whether the United States may be sued for a breach of such a duty must be examined. The United States, of course, may not be sued without its consent. ${ }^{219}$ In 1946, Congress granted to Indian tribes the right to sue the federal government for claims arising out of their dealings with the United States prior to that year. ${ }^{\mathbf{2 2 0}}$ For those claims arising after 1946, finding consent becomes a bit more difficult; yet the right of tribes to sue the United States both in federal district courts and in the Court of Claims has been recognized.

The Court of Claims has jurisdiction over claims against the United States "founded either upon the Constitution, or any Act of Congress, or any regulation of an executive department, or upon any express or implied contract with the United States, or for liquidated or unliquidated damages in cases not sounding in tort . . .."221 In Mason v. United States ${ }^{222}$ this provision alone was relied on to provide the Court of Claims with jurisdiction to hear a case in which the Osage Indians claimed the United States had breached its fiduciary duty by paying certain Oklahoma estate taxes. But if this provision were not enough, there is explicit statutory authorization for Indians to bring suit against the United States in the Court of Claims:

The Court of Claims shall have jurisdiction of any claim against the United States accruing after August 13, 1946 , in favor of any tribe, band, or other identifiable group of American Indians residing within the territorial limits of the United States ... whenever such claim is one arising under the Constitution, laws or treaties of the United States, or Executive orders of the President,

Tribe v. United States, 364 F.2d 320 (Ct. Cl. 1966); Seneca Nation v. United States, 173 Ct. Cl. 917 (1965); Seneca Nation v. United States, 173 Ct. Cl. 912 (1965); Oneida Tribe v. United States, 165 Ct. Cl. 487 , cert. denied, 379 U.S. 946 (1964).

${ }^{219}$ This result flows from the general doctrine of sovereign immunity. See, e.g., The Western Maid, 257 U.S. 419 (1922) (Holmes, J. ) (tort claim).

22025 U.S.C. $\S \S 70 \mathrm{a}-\mathrm{w}$ (1970), as amended 25 U.S.C. $\$ \S 70 \mathrm{a}-\mathrm{w}$ (Supp. II, 1972) and 25

U.S.C. \$\$ 70a-w (Supp. III, 1973); see Federal Indian Law, supra note 9, at 356-59.

22128 U.S.C. $\$ 1491$ (1970), as amended 28 U.S.C. $\$ 1491$ (Supp. II, 1972).

222461 F.2d 1364 (Ct. Cl. 1972), rev'd on other grounds, 412 U.S. 391 (1973). 
or is one which otherwise would be cognizable in the Court of Claims if the claimant were not an Indian tribe, band or group. ${ }^{223}$

In Klamath and Modoc Tribes $v$. United States ${ }^{224}$ this provision was construed to give the Court of Claims jurisdiction to grant monetary damages but not equitable relief.

District courts also have cognizance over Indian claims against the United States. In Manchester Band of Pomo Indians, Inc. $v$. United States, ${ }^{225}$ the government claimed that tribes seeking relief for a breach of fiduciary duty had no redress except in the Court of Claims. The court rejected the argument, however, on several theories. First, the court held that it had jurisdiction under the statute that confers on district courts in actions where the amount in controversy does not exceed $\$ 10,000$, a jurisdiction similar to the jurisdiction of the Court of Claims. ${ }^{226}$. Second, and more important, district courts explicitly have been given power over actions against the United States brought by Indian tribes. ${ }^{227}$ The court also relied on a statute giving district courts power to order federal officers to perform their duties. ${ }^{228}$ And finally the court determined that the Indian band qualified as a person aggrieved by an agency action under section 702 of the Administrative Procedure Act. ${ }^{229}$ A tribe thus could seek review of the actions of various officials in the Department of the Interior; and a district court could, under section 706, either compel agency action which had been delayed, or set aside certain agency actions. ${ }^{230}$ This last capability suggests that leases made or approved by the Secretary of the Interior may be set aside by a court if his action can be shown to be "arbitrary, capricious, an abuse of discretion, or otherwise not in accordance with law...."231

Most of these arguments were accepted by the Ninth Circuit in Rockbridge $v$. Lincoln. ${ }^{232}$ In that case, the Navajo Indians sued to require the Commissioner of Indian Affairs and the area di-

22328 Ü.S.C. § 1505 (1970).

${ }^{224} 174 \mathrm{Ct}$. Cl. 483 (1966).

225363 F. Supp. 1238 (N.D. Cal. 1973).

22628 U.S.C. $\S 1346(a)(2)(1970)$.

${ }^{227} 28$ U.S.C. $\S 1362(1970)$. This statute is similar in scope to 28 U.S.C. $\S 1505$ (1970). See text accompanying note 223 supra.

22828 U.S.C. $\S 1361$ (1970).

${ }^{229} 5$ U.S.C. \& 702 (1970).

2305 U.S.C. $\$ 706(1)$, (2) (1970).

2315 U.S.C. $\$ 706(2)(A)(1970)$.

${ }^{232} 499$ F.2d 567 (9th Cir. 1971). 
rector of the Navajo Reservation to promulgate and enforce, pursuant to federal statute, maximum price regulations governing licensed traders on the reservation. The district court had dismissed the suit for lack of jurisdiction, but the court of appeals reversed, holding that the federal courts have power to order the Commissioner to enforce regulations under section 706 of the Administrative Procedure Act. ${ }^{233}$ That the Commissioner was given sole power to issue regulations did not mean that he could simply decide not to regulate, especially in light of the established rule that statutes passed for the benefit of the Indians are to be construed in their favor when interpretation is in doubt. ${ }^{234}$

It thus seems well founded that if an Indian tribe can demonstrate that the Government, in its role as "guardian," has breached its duty to the Indians by negotiating or approving a grossly unfair lease, the tribe has redress in the federal courts. The tribe's remedy may be in damages, or, under some circumstances, in having the lease set aside as unlawful agency action.

\section{B. The Scope of the United States' Duty to the Indians in Lease Negotiations}

Once the jurisdictional question is resolved, the substantive question remains: $\mathrm{By}$ what standards is federal governmental action on behalf of the Indians to be judged? The answer was given in unequivocal terms by the United States Supreme Court in Seminole Nation v. United States: ${ }^{235}$

$[\mathrm{T}]$ his Court has recognized the distinctive obligation of trust incumbent upon the Government in its dealings with these dependent and sometimes exploited people. . .. In carrying out its treaty obligations with the Indian tribes, the Government is something more than a mere contracting party. Under a humane and self imposed policy which has found expression in many acts of Congress and numerous decisions of this Court, it has charged itself with moral obligations of the highest responsibility and trust. Its conduct, as disclosed in the acts of those who represent it in dealings with the Indians, should therefore be judged by the most exacting fiduciary standards. ${ }^{236}$

2335 U.S.C. $\$ 706(2)(A)(1970)$.

${ }^{234} 449$ F.2d at 571 ; see, e.g., Squire v. Capoeman, 351 U.S. 1, 6-7 (1956); Carpenter v. Shaw, 280 U.S. 363,367 (1930).

235316 U.S. 286 (1942).

${ }^{236}$ Id. at $296-97$ (citations and footnote omitted) (emphasis supplied). 
The obligation in question in Seminole Nation arose out of an agreement between the tribe and the United States, as the above-quoted language indicates. The case also dealt with treaty obligations.

Still, the standard imposed on the Government by Seminole Nation has been applied where the Government was acting on behalf of the Indians and pursuant to no treaty obligation. In Manchester Band of Pomo Indians, Inc. v. United States, ${ }^{237}$ for instance, the district court adopted the "exacting fiduciary standards" test of Seminole Nation in finding that the Government had breached its duty to the band by not making certain Indian funds productive, and by investing tribal funds in securities of the United States bearing less interest than others which might have been legally purchased with Indian funds. ${ }^{238}$

The Seminole Nation test was also applied in Navajo Tribe $v$. United States. ${ }^{239}$ In that case the tribe successfully claimed that the United States had breached its duty by not turning over to the tribe benefits of an assignment of a gas and oil lease when the tribe's lessee assigned the lease to the United States for a nominal consideration. The conduct of the Government was analogized to that of a fiduciary diverting to his personal profit an opportunity gained in the exercise of his repsonsibilities. ${ }^{240}$

The conduct of the United States in relation to various sales of land by the Seneca Indians in the late eigtheenth and early nineteenth centuries was found actionable in Seneca Nation $v$. United States. ${ }^{241}$ The federal government's "responsibility was not merely to be present at the negotiations or to prevent actual fraud, deception, or duress alone; improvidence, unfairness, the receipt of unconscionable consideration would likewise be of federal concern."242 The court concluded: "It can be said . . . that the sales-agreement must be treated as one between the Indians and the United States (as well as between the Indians and the purchaser) because the Government's participation and consent was a necessary prerequisite under the Trade and Intercourse Act." ${ }^{43}$ Further principles of "fair and honorable deal-

${ }^{237} 363$ F. Supp. 1238 (N.D. Cal. 1973).

${ }^{238} \mathrm{Id}$. at 1243, 1245. See also Menominee Tribe v. United States, 59 F. Supp. 137 (Ct.

Cl. 1945); Menominee Tribe v. United States, 101 Ct. Cl. 10 (1944).

239364 F.2d 320 (Ct. Cl. 1966).

$240 \mathrm{Id}$. at 324.

241173 Ct. Cl. 917 (1965).

242 Id. at 925.

${ }^{243} \mathrm{Id}$, at 926 . The Act referred to in the quotation, now codified as 25 U.S.C. $\$ 177$ (1970), forbids the sale or conveyance of any Indian lands without consent of the federal government. 
ings" required the Government to account for agreements it sanctioned in the absence of assurances of fair consideration for the Indians. ${ }^{244}$

As a fiduciary the United States has an obligation to protect the Indians not only against third parties but even against themselves, if necessary. In Oneida Tribe $v$. United States, ${ }^{245}$ the Court of Claims held that the federal government had a duty to prevent wasteful and unlawful timber cutting by certain Oneida Indians on their reservation. The court found, however, that the Government had done enough to satisfy its duty.

The Supreme Court, in a recent decision, simply assumed that the federal government had a fiduciary duty to the plaintiff tribe. ${ }^{246}$ The Court decided that a federal standard should govern the relationship between the tribe and the United States. Adopting Professor Scott's well-known test, the crucial inquiry for the Court was whether the Government had "exercise[d] such skill and care as a man of ordinary prudence would exercise in dealing with his own property." 247 The Court went on to hold that the Government had not breached its duty, but had permissibly relied on a decision of the Supreme Court which was unquestioned at the time it paid Oklahoma estate taxes on property held in trust for the Osage Indians.

It is apparent that the Government has taken upon itself the panoply of burdens implicit in a strict fiduciary relationship. Especially from the Seneca Nation case, it is evident that this relationship requires federal officials, in their supervision of Indian leasemaking, to protect Indians against unconscionable contracts. This duty should not be negated by the Indians' participation in negotiating or approving the terms of a lease. ${ }^{248}$ To allow such nominal participation to destroy the United States' duty would defeat the entire purpose of the fiduciary relationship-to protect those in a dependent position against those who would take unfair advantage of them.

Because the United States thus has a duty to protect the Indians against unconscionable leases, a tribe should be able to recover damages from the United States upon demonstrating the inadequacy of consideration for a granted lease. A tribe should also be able to set aside an unconscionable agreement as

244173 Ct. Cl. at 926.

245165 Ct. Cl. 487 (1964).

${ }^{246}$ United States v. Mason, 412 U.S. 391 (1973).

${ }^{247}$ Id. at 398. See 2 A. Scott, The Law OF Trusts 1408 (3d ed. 1967).

${ }^{248}$ Cf. Osage Nation v. United States, 97 F. Supp. 381 (Ct. Cl.), cert. denied, 342 U.S. 896 (1951); FEDERAL INDIAN LAw, supra note 9, at 358-59. 
improper agency action which serves only to enrich the third party lessee at the expense of the tribe.

\section{Conclusion}

Even throughout the sometimes shameful history of mistreatment of American Indian tribes by the federal government, the tribes have generally been recognized as retaining at least some of the attributes of sovereignty. As "domestic dependent nations" tribes have retained the power to tax, one of the principal attributes of a sovereign.

To the extent that state taxation of lessees of Indian lands interferes with the tribes' sovereign rights to raise money and to provide for the welfare of their people, the taxation should be found invalid, unless the tax serves some limited state regulatory purpose or is specifically authorized by Congress. In addition, clauses in leases which purport to bind Indian tribes not to tax their lessees should be considered void to the extent they bind future tribal governments and prevent them from fulfilling their sovereign governmental functions. This follows from the wellestablished doctrine that a sovereign cannot barter away inherent attributes of its sovereignty.

Even if none of the above propositions is considered correct, an Indian tribe is owed a fiduciary duty by the United States Government, which has forcibly assumed the role of guardian and protector of the "domestic dependent nations" of American Indians. This duty is enforceable in the federal courts, and unfair leases negotiated by the Government or under Government supervision should give rise to damages actions by the Indian tribes against the United States. 